University of Warwick institutional repository: http://go.warwick.ac.uk/wrap

This paper is made available online in accordance with publisher policies.

Please scroll down to view the document itself. Please refer to the repository record for this item and our policy information available from the repository home page for further information.

To see the final version of this paper please visit the publisher's website. Access to the published version may require a subscription.

\author{
Author(s): Barlow J, Tennant R, Goens C, Stewart-Brown S, Day C \\ Article Title: A systematic review of reviews of interventions to promote \\ mental health and prevent mental health problems in children and young \\ people \\ Year of publication: 2007 \\ Link to published version: \\ http://www.pavpub.com/pavpub/journals/jpmh/samples/0307sample.pdf \\ Publisher statement: \\ Copyright assignment. \\ You should understand that in submitting your article for publication you \\ are assigning thecopyright of this to Pavilion Publishing (Brighton) Ltd. \\ Authors and illustrators may use their own material elsewhere after \\ publication without permission but Pavilion Publishing asks that full \\ acknowledgement be given to the original source. \\ Please contact Pavilion or the Editor if you are in any doubt about \\ copyright.
}




\title{
A systematic review of reviews of interventions to promote mental health and prevent mental health problems in children and young people
}

\begin{abstract}
Background: There is a growing policy imperative to promote positive mental health as well as preventing the development of mental health problems in children. This paper summarises the results of published systematic reviews evaluating interventions to promote mental health and prevent mental illness in children.
\end{abstract}

Method: A search was undertaken of ten electronic databases using a combination of medical subject headings (MeSH) and free text searches. Systematic reviews covering mental health promotion or mental illness prevention interventions aimed at infants, children or young people up to age 19 were included. Reviews of drug and alcohol prevention programmes or programmes to prevent childhood abuse and neglect were excluded because these have been the subject of recent good quality reviews of reviews.

Critical appraisal of all studies was undertaken using a standardised appraisal tool for systematic reviews. Where possible effect sizes and 95\% confidence intervals are reported. A narrative summary has been provided.

Results: A total of 27 systematic reviews were included and grouped pragmatically under the following headings: parenting interventions; programmes for the prevention of anxiety and depression, programmes to promote self esteem, violence and aggression prevention programmes, school-based programmes, and general reviews. Included studies targeted a range of risk and protective factors, and a range of populations (including both parents and children). While, many lacked methodological rigour, overall, the evidence is strongly suggestive of the effectiveness of a range of interventions in promoting positive mental well-being, and reducing key risk factors for mental illness in children.

Conclusion: A variety of programmes have been shown to be effective in promoting children's mental health, albeit with modest effect sizes. Based on this evidence, arguments are advanced for the preferential provision of early preventive programmes. 


\section{Introduction}

Around 1 in 10 children in the UK aged between 5 and 15 have a mental health problem. Rates are higher for boys than girls; $11.4 \%$ of boys having a diagnosed condition, compared with $7.6 \%$ of girls (Melzer, 2000). The most common mental health conditions for children and young people are emotional disorders (depression, anxiety and obsessions), hyperactivity (inattention and over-activity), and conduct disorders (awkward, troublesome, aggressive and antisocial behaviour) (ibid). Rates for all conditions increase with age: around $8 \%$ of children aged $5-10$ and $12 \%$ of children aged 11-15 have a mental health problem (ibid). Rates vary with ethnicity being highest in black children (12\%) and lowest in Indian children (4\%) (ibid).

The long-term consequences of mental health problems in childhood are considerable. At 33 years, children who had conduct disorder are more likely to be on benefits or homeless, to have been a teenage parent, and to suffer poorer health than their peers (Collishaw, 2004). Nearly eleven percent of children with conduct disorder are unemployed at 33, compared with $3.7 \%$ of those without conduct disorder (ibid).

A range of biological, environmental and psychological risk and protective factors are amenable to intervention and evidence of the effectiveness of interventions is growing $(\mathrm{WHO}, 2004)$. This paper reports the results of a systematic review of reviews of interventions aimed at minimising risk factors or maximising protective factors associated with the promotion of mental health and the prevention of mental illness. 


\section{Methods}

Databases searched

We searched ten electronic databases (PsychInfo, Medline, ERIC, ASSIA, Social Services Abstracts, Sociological Abstracts, HealthPromis, Child data, CINHAL and the Cochrane database of systematic reviews) using a combination of medical subject headings (MeSH) and free text search. The search strategy was developed by identifying search terms corresponding to a range of risk and resilience factors and modifying searches used in earlier high-quality published reviews (see Tennant et al, 2005, for full details). Additional articles were identified by hand-searching references from included articles.

\section{Inclusion criteria}

As a result of the broad nature of the subject, we restricted our search to systematic reviews, but excluded reviews of reviews in order to avoid excessive double counting:

- Papers were included if the interventions were aimed at infants, children or young people aged 19 or under or included data for this age group.

- We excluded reviews of drug and alcohol abuse, or physical or mental abuse and neglect as these have been the subject of recent good quality systematic reviews of reviews (Barlow et al, 2007; WHO, 2006). 
Abstracts and articles were independently assessed against the inclusion criteria by two reviewers. Differences were resolved with a third reviewer.

\section{Critical appraisal}

Each study was critically appraised using the eight-point Critical Appraisal Skills Programme appraisal tool for systematic reviews (Critical Appraisal Skills Programme, 2002), and awarded a score out of 16 using the following criteria (a maximum of 2 points for each criterion that was fully met; 1 point for partially met and 0 points for not met): clearly focused question; only includes RCTs or controlled trials; evidence of a systematic search; appraisal of quality of included studies; appropriate combination of studies; statistical results presented; precision of results (e.g. confidence intervals or $\mathrm{p}$ values); applicability to UK urban population. Studies were independently assessed by two reviewers and differences were resolved through discussion. No reviews were rejected on the basis of a low quality score. However, those with a low quality score are likely to be of a less robust quality, and the findings of these reviews have been treated with caution.

\section{Data synthesis}

The results of individual outcomes have been presented for each review. Where possible effect sizes and 95\% confidence intervals have been abstracted or calculated. In the absence of these, a narrative summary has been provided. 


\section{Results}

1153 abstracts were retrieved. 27 systematic reviews met our inclusion criteria. Reviews were grouped pragmatically according to their focus. Most of the groupings were based on intervention aims (e.g. parenting, promotion of self esteem, violence prevention), and one was based on settings (school based programmes). The last group included general reviews of mental health promotion programmes. It is important to recognise the potential overlap between these groups. For example, some self-esteem promotion programmes are school-based, and one of the ways of preventing violence is to improve parenting.

\section{Parenting interventions}

The search yielded seven systematic reviews of parenting programmes (Barlow et al., 2004; Bakermans-Kranenburg et al., 2003; Barlow \& Parsons, 2003; Barnes \& Freude-Lagevardi, 2003; Barlow \& Stewart-Brown, 2000; Serketich \& Dumas, 1996; Cedar \& Levant, 1990). Five of these reviews examined the effectiveness of behavioural and other types of structured parenting programmes for all ages of children. Two reviews focused on early preventive interventions; one covered programmes aiming to enhance positive parental behaviours across four categories (sensitivity; support; representation; and two or more of these combined) (BakermansKranenburg et al., 2003); the second covered programmes aiming to improve parenting, family functioning and young children's mental health more generally (Barnes \& Freude-Lagevardi, 2003). Two reviews were excluded: one summarising the literature on parenting support programmes because it 
included 50 reviews in addition to primary studies (Moran et al., 2004), and the second summarising only review level evidence about the effectiveness of home visiting programmes (Bull et al., 2004), and therefore likely to involve considerable double counting. This group of reviews had the highest quality ratings, only two studies scoring below 10 (Cedar \& Levant, 1990; Serketich and Dumas, 1996).

Insert table 1 here

The results showed that a number of peri-natal interventions are effective in improving outcomes for mothers and infants:

- The Brazelton Neonatal Behavioural Assessment is an effective and cost-effective universal intervention to enhance parents' sensitivity to their new baby (Barnes \& Freude-Lagevardi, 2003).

- There is evidence of the effectiveness of a range of interventions to improve parental sensitivity $(d=0.3395 \% \mathrm{Cl} 0.25-0.41)$ and attachment $(d=0.2095 \% \mathrm{Cl} 0.04-0.35)$ in high risk families (Bakermans-Kranenburg et al., 2003). Results for attachment interventions for low-risk families were not statistically significant. The finding that programmes were more effective if they started at 6 months of age (rather than at birth or before birth) and lasted a relatively short duration, conflicts were the findings of other reviews, and may only apply to early programmes that focus solely on parental sensitivity or infant attachment. 
Several reviews demonstrated that group-based parenting interventions improved the emotional and behavioural adjustment of children:

- The evidence was much stronger for children aged 3 to 10 years old (Barlow et al., 2000) than it was for those less than 3 years of age (Barlow et al., 2003). Positive effects were also identified for programmes directed at black or mixed ethnic origin parents (Barlow et al., 2004).

- One systematic review identified significant improvements in children's self-esteem $(d=0.38)$ (Cedar \& Levant, 1990).

- Positive effect sizes were observed for specific programme formats, such as behavioural parenting programmes (Serketich and Dumas, 1996) and parent effectiveness training (Cedar \& Levant, 1990).

- There were inconsistent findings as regards the most effective format for delivery, one review showing no difference between individual and group-based programmes (Cedar \& Levant, 1990), and another favouring group-based programmes (Barlow et al., 2000). This was most probably due to the different time periods during which the reviews were conducted.

\section{Anxiety \& Depression Prevention Programmes}

Three systematic reviews were identified of initiatives to prevent anxiety \& depression (Merry et al., 2004; Jané-Llopis et al., 2003; Andrews \& Wilkinson, 2002). The three reviews obtained quality scores of 9,15 and 5 
respectively, and the results of two should therefore be treated with caution (Merry et al., 2004; Andrews \& Wilkinson, 2002).

\section{Insert table 2 here}

The first review compares the relative effectiveness of universal and targeted programmes (of three types - psychological; educational and psychoeducational) for children aged $5-19$ years across 21 RCTs (Merry et al., 2004), and the second compares the relative effectiveness of different programme formats (length, theoretical basis, programme provider) of a broad range of universal, selected and targeted interventions for depression across all ages (including adults) based on five broad categories of interventions - behavioural, cognitive, competence-based, educational and social support (Jané-Llopis et al., 2003). One further low quality review provides a qualitative summary only of 20 RCTs that used cognitivebehavioural therapy to prevent anxiety, depression or substance abuse (Andrews \& Wilkinson., 2002).

- The first review showed small but statistically significant changes in depression scores following psychologically-based interventions such as stress-management or problem-solving skills $(d=-0.26$, $95 \% \mathrm{Cl}-0.40$ to -0.13 ) (Merry et al., 2004). The results also showed slightly better levels of effectiveness for targeted $(R D=-$ $0.26, \mathrm{Cl}-0.40$ to -0.13$)$ than for universal programmes $(\mathrm{d}=-0.21$, 
$95 \% \mathrm{Cl}=-0.1510-0.01)$, although the authors note that the difficulties of targeting this type of programme may mean that universal interventions are more practical.

- $\quad$ The results from 54 RCTS in the second review showed an $11 \%$ improvement in depressive symptoms following the pooling of data from a variety of interventions for both adults and children. Similar improvements were observed for children below the age of 14 and for adolescents (15-18 years) (Jané-Llopis et al., 2003).

- The third review suggests that cognitive behavioural therapy may be effective in preventing depressive and anxiety disorders in both universal and targeted groups but that the efficacy of these approaches has not been demonstrated in routine practice (Andrews \& Wilkinson, 2002). The results of this low quality review should be treated with caution.

\section{Self-esteem Promotion Programmes}

We found two systematic reviews addressing the promotion of self-esteem (Ekeland et al., 2004; Haney \& Durlak, 1998). One high-quality review (score of 14) based on 23 randomised and quasi-randomised controlled trials provided data about interventions whose primary purpose was to improve self-esteem in children between the ages of 3 and 20, and excluded children with physical or mental handicap and chronic somatic or physical disease (Ekland et al., 2004). The second review was less rigorous (score of 8) and was based on the findings of 102 studies with a control group (either 
attention-placebo or no treatment) of a broader range of interventions for children ranging from toddlers to 18 years of age, including commercially available programmes, social skills training, parent-training, and behaviour modification (Haney \& Durlak, 1998). The ethnicity of participants was not specified in either review. Both studies used self-esteem scores as the principal outcome measure.

Insert table 3 here

- The first of these reviews provided evidence to suggest that exercise as part of a comprehensive intervention has positive short-term effects on self-esteem ( $d=0.51,95 \% \mathrm{Cl} 0.15-0.88)$, and is also effective on its own both for healthy children ( $d=0.53,95 \% \mathrm{Cl}-0.04$ to 1.09$)$ and children with defined problems $(d=0.49,95 \% \mathrm{Cl} 0.17$ to 0.82$)$ (Ekeland et al., 2005).

- The second, found greater effect sizes for programmes that focused on self-esteem $(d=0.57)$ than for programmes that addressed other aspects of development such as behaviour or social skills ( $d=0.27)$ (Haney \& Durlak, 1998).

\section{Violence and aggression prevention programmes}

Six systematic reviews, covering over 500 studies of violence and aggression prevention programmes were identified (see below for details). Half of the reviews were based on the findings of RCTs with the remaining 
half including non-controlled studies. Quality scores ranged from 8 to 13 , with only two reviews achieving scores over 10 (Losel and Beelmann, 2003; Mytton et al., 2002) (11 and 13 respectively).

\section{Insert table 4 here}

A wide range of interventions were reviewed including:

- social skills training (Losel \& Beelmann, 2003; Mytton et al., 2002 \& Quinn et al, 1999);

- school-based violence prevention programmes (Mytton et al., 2002);

- parent, teacher and child focused interventions (Bryant et al., 1999);

- family-focused interventions (e.g. home-visiting programmes, day care/preschool, school-based, home/community and multi systemic therapy programmes) (Farrington \& Welsh, 2003);

- mainstream service programmes (counselling and casework etc) for minority juvenile delinquents (Wilson et al., 2003).

A wide range of outcome measures were reported and a majority of studies produced overall measures of effect size for all outcomes combined (Farrington \& Welsh, 2003; Losel \& Beelman, 2003; Mytton et al., 2003; Quinn et al., 1999) and across all treatment modalities (Wilson et al., 2003). Other studies reported results for individual outcomes including changes in teacher or parental reports of aggressive behaviour and changes in delinquency, school exclusion or contact with the police (Losel and Beelman, 
2003; Myton et al., 2002). No study provided reports of clinical outcomes such as, for example, diagnoses of conduct disorder.

- Studies that provided pooled outcome data showed small to moderate effects in favour of the intervention groups ranging from 0.14 (Dubois et al, 1999) to 0.38 (Losel \& Beelmann, 2003).

- Three reviews suggested that child social skills training was fairly effective for outcomes relating to antisocial behaviour (effect sizes ranging from 0.22 to 0.38 ) (Losel \& Beelmann, 2003; Mytton et al., 2002; Quinn et al., 1999), including those delivered in school settings.

- One review also showed small decreases in contact with police, recidivism and school referral (mean effect size $=0.16)($ Losel \& Beelmann, 2003).

- A further review showed that mainstream service programmes (counselling and casework etc) without cultural tailoring showed very small effects across treatment modalities for minority juvenile delinquents (mean effect size - 0.11), and also for the majority juvenile delinquents (mean effect size - 0.17) (Wilson et al., 2003).

Larger effect sizes were generally obtained for social and cognitive outcome measures compared with changes in anti-social behaviour. This may reflect the short follow-up time in many of the included studies (Nicholas \& Broadstock, 1999). 
- One review reached the conclusion that the effects of programmes for preventing aggressive behaviour in pre-schoolers are modest at best (Bryant et al., 1999). However, these findings were based on low quality studies in which no quantitative data were provided. The principal conclusion that can be drawn from this review is that there appears to be less evidence about programmes for this age group.

- Family-based prevention programmes (such as home visiting, day care/preschool programmes, school-based programmes, home/community programmes and multi systemic therapy programmes) produced a moderate overall effect size $(d=0.32)$, corresponding to a decrease in offending from $50 \%$ in the control groups to $34 \%$ in the intervention groups. Although these interventions were not uniformly effective the authors conclude that family-based programmes can be effective in improving delinquency and antisocial behaviour. They suggest that the most effective programmes used behavioural parent training, and that the least effective programmes were based in schools (Farrington \& Welsh, 2003). Examples of effective interventions included home visiting, day care/preschool home/community and multi-systemic therapy.

\section{School-based programmes}

We found two good quality systematic reviews of school-based programmes (Wells et al, 2003; Wilson et al. 2001) (quality rating of 10 and 11 respectively). The first of these focused on mental health interventions (Wells 
et al., 2003), and the second examined prevention programmes aimed at reducing crime, school dropout and non-attendance in addition to a range of other conduct problems (Wilson et al., 2001). This review also identified the characteristics of successful programmes.

Insert table 5 here

Both reviews included programmes for primary and secondary school-aged children. Although no information was provided in either review about the effectiveness of programmes for different socio-economic or cultural groups, both included studies that had been carried out with minority ethnic groups, and also included participants from socially deprived areas. Both reviews included some studies that had been carried out with young people demonstrating violent or aggressive behaviour. One review focused on child mental health promotion and included three types of intervention: wholeschool approaches that involved all the teachers, students and wider school community; classroom approaches that were limited to curriculum changes or changes in the classroom teacher's approach; and intermediate approaches that extended beyond the classroom to other parts of the school but only involved some students or teachers (Wells et al., 2003). The second focused on the prevention of conduct problems, crime reduction and non-attendance at school (Wilson et al., 2001). This included environmentally-focused interventions, such as programmes to establish norms or expectations about behaviour, school management interventions, and individually-focused interventions such as self-control or self- 
competency programmes, mentoring, tutoring and social work, or community-based activities.

- These reviews both found evidence of the effectiveness of programmes that adopted a whole-school approach, and that were aimed at the promotion of mental health as opposed to the prevention of mental illness (Wells et al., 2003; Wilson et al., 2001). The authors suggested that long-term interventions that promote the positive mental health of all students and involve changes to the school climate are likely to be more successful than brief class-based mental illness prevention programmes although no statistical evidence is provided to support this finding.

- The second review showed that there was limited evidence of effectiveness in terms of delinquency ( $d=.0495 \% \mathrm{Cl}-0.03$ to 0.11 ), and other outcomes ( $d=-.1795 \% \mathrm{Cl} 0.09$ to 0.25$)$ (Wilson et al., 2001). The authors conclude that the size of the average effect for each outcome was small, and that there was considerable heterogeneity across studies (ibid).

\section{General Reviews}

Seven reviews were identified that covered a range of interventions aimed at improving the mental health of children and adolescents (Kulic and Horne, 2004; Nelson et al., 2003; Dubois et al., 2002; Andrews and Wilkinson, 2002; 
Greenberg et al., 2001; Durlak \& Wells, 1998; and Durlak \& Wells, 1997). The general quality of these reviews was moderate, with scores ranging from 4 to 9 out of a possible 16 . The results of all of the studies in this group should therefore be treated with caution. Three reviews do not provide data and have not therefore been summarised below (Kulic and Horne, 2004; Andrews and Wilkinson, 2002; Greenberg et al., 2001). It should also be noted that this category included intervention studies which are likely to have been included in other more focused reviews (i.e. school-based and parenting programmes).

Insert table 6 here

- One review showed that a range of behavioural and cognitive behavioural interventions were effective in reducing problems and increasing competencies in both children and adolescents (Durlak and Wells, 1997). Effect sizes ranged from 0.93 (0.66 to 1.19) for interpersonal problem solving interventions, to $0.16(-0.04$ to 0.36$)$ for parenting interventions. The non-significant finding for parenting programmes contradicts the results of a number of other reviews on parenting and is likely to reflect partial coverage of parenting studies.

- A second review of universal interventions (e.g. Person-centred such as affective education and problem-solving; Environment-centred such as school-based and parenting programmes; and Transition 
programmes addressing school-transition, divorce/ bereavement etc) for children aged between 2 and 18 years, found evidence of greater effectiveness in the early years (aged 2-7) than in older children (over 7) (Durlak \& Wells, 1998). Significant positive effects were observed for a range of indicated interventions, effect sizes being higher for interventions with children showing externalising problems $(0.72,95 \%$ $\mathrm{Cl} 0.52-0.92)$ than internalising problems $(0.49,95 \% \mathrm{Cl} 0.39-0.60)$ (Durlak and Wells, 1998).

- The third review focusing on a range of interventions (home visitation, parent training and pre-school education) for children less than five years of age also observed larger effect sizes for cognitive outcomes in pre-school children $(d=0.52)$ than in children attending kindergarten $(d=0.30)$ (Nelson et al., 2003). There was evidence of effectiveness for social-emotional outcomes for children up to grade $8(d=0.27)$ and also for children in high-school and beyond $(d=0.33)$.

- A fourth review which examined the effects of mentoring programmes delivered in school and community settings showed that structured activities and ongoing training, especially those involving parents) were more effective than those without these components (overall mean effect size of 0.18) (Dubois et al., 2002). 


\section{DISCUSSION}

The approach we have adopted of reviewing reviews has the advantage of enabling coverage of a wide range of interventions and making comparisons of the relative effectiveness of different approaches. However, it is inevitable with such an approach that there is an element of double counting, in which the results of individual studies contribute to more than one review. It should not therefore be assumed that the results of each group of programmes and each review are independent of one another.

Many of the reviews that undertook meta-analyses did not provide effect sizes for individual outcomes and individual interventions, precluding the possibility of assessing which type of intervention is best for which outcomes. A number of the reviews also searched for wide-ranging interventions and only identified small numbers of studies for some types of intervention (e.g. parenting programmes). The failure to be systematic and the inappropriate combination of wide-ranging programmes may explain some of the discrepancies that were identified, particularly in terms of the reviews that showed a lack of effectiveness.

Overall, the evidence is of variable quality, and much of it has been carried out in the U.S., which may limit its generalisability to the U.K. Information was lacking from all the reviews about the relative effectiveness of different interventions in different socio-economic and ethno-racial groups, and of the crucial ingredients of successful programmes in terms of the optimal 
programme onset, intensity and duration, delivery format and staff characteristics.

Bearing these caveats in mind, the research suggests that a variety of programmes are effective in promoting mental health and preventing mental health problems in children and young people. The effect sizes produced from studies where it was possible to make such calculations were, however, relatively modest.

Parenting interventions in the early years showed overall effect sizes of between 0.2 and 0.6, (compared with effect sizes of around 0.2 to 0.4 for conduct disorder and violence prevention programmes, around 0.2 to 0.3 for anxiety and depression, and around 0.3 to 0.5 for self-esteem programmes). These effect sizes mean that following intervention, the average parent or child was functioning better than between $62 \%$ and $66 \%$ of control group parents/children.

Few studies provided robust follow-up data, making it difficult to establish whether the positive effects observed are sustained in the medium to long term. The lack of follow-up data may also make it difficult to identify 'sleeper effects' (i.e. positive outcomes that only emerge after the end of an intervention) (Nicholas \& Broadstock, Lister-Sharp et al., 1999; StewartBrown, 2004). 
The findings identifying the effectiveness of high-quality pre-school programmes such as the Perry Pre-School Programme and Head Start, which are aimed at improving self-esteem and behaviour as well as non mental health outcomes such as educational achievement, are supported by other reviews of reviews (NHS Centre for Research \& Dissemination, 1997). The evidence about school-based programmes also broadly reflects that of two further reviews of reviews (Stewart-Brown et al., 2004; Lister-Sharp et al., 1999), which show that whole-school approaches involving changes to the school environment, personal skills development in class, and parental participation are on the whole more effective than purely classroom-based programmes (ibid). This review also found that interventions aimed at mental health promotion were more effective than those targeting mental health problems and lifestyle factors such as substance misuse (ibid). While one further review of reviews (Nicholas \& Broadstock, 1999 - not included here) found limited evidence of the effectiveness for violence prevention programmes, particularly when delivered in school settings, the authors attribute this result to the fact that schools may not capture the highest risk students and note that there are examples of some successful school-based violence prevention programmes. They also demonstrate that some of the school-based violence programmes had short follow-up periods which may miss important 'sleeper effects' that do not emerge until some time after the programme.

Much, although not all, of the research that has been reviewed is concerned with specific risk factors for mental health problems, and factors that protect against, or make people more resilient to, mental health problems. While this 
research shows that a wide range of interventions aimed at addressing specific risk and protective factors can be effective, and also provides some evidence of reductions in proximal risk factors such as stress, complexities in the causal pathways for mental health problems make it difficult to link a reduction in specific risk factors to a reduction in mental health problems. There is, however, clear evidence that a multiplication of risk factors is associated with an increasing risk of mental health problems, and strategies to reduce exposure to risk factors or minimise their impact are therefore likely to have a positive effect on morbidity in the future.

The findings also suggest that there has been considerably more evaluation of the effectiveness of interventions to reduce conduct disorder problems than of interventions aimed at reducing anxiety and depression. This may be due in part to the more socially disruptive nature of conduct disorder, making it both easier to identify and a higher priority for intervention. The findings show, nevertheless, similar overall effect sizes for programmes to minimise factors associated with both conduct disorder, and anxiety and depression prevention programmes.

Although some of the interventions included in this research have been classified according to a specific mental health outcome, many of the risk and protective factors discussed are common to several mental health problems. For example, poor parenting is associated with conduct disorder, anxiety and depression, and low self-esteem. In practical terms therefore, it 
may make more sense for policy makers to utilise interventions that target certain risk and protective factors (e.g. parenting) rather than others.

This review did not include findings about interventions to improve child abuse and neglect because these have already been the subject of a review of reviews (Barlow et al., in press), which showed that while there was limited evidence of effectiveness of services (such as home visiting, parenting programmes and a range of other family-based interventions) in improving objective measures of abuse and neglect, there was nevertheless, good evidence of modest benefits in improving a range of outcomes that are associated with these problems including parental and family functioning, and child development. The results also showed some interventions (e.g. media-based and perinatal coaching) to be ineffective with high-risk families.

\section{Conclusion}

In this review we have presented data on a range of different programmes that are aimed at influencing risk or protective factors for mental health, operating at different stages in children's lives. However, judgements about the relative effectiveness of different interventions are problematic. For example, is a programme that appears to contribute to improvements in a young child's behaviour more or less valuable than one that improves an adolescent's self-esteem? Current limitations in our knowledge about the strength of the association between risk and protective factors and medium to long-term mental health outcomes means that it is difficult to quantify which of the different preventative interventions will have the greatest effect. 
However, common sense would dictate that prevention is better than cure and on that basis early intervention is important. Effect sizes for these early programmes are similar to those for later programmes, and arguments can therefore be made for preferential investment in home visiting, attachmentbased and early parenting programmes, especially where resources are limited. 


\section{References}

** Included Studies

**Andrews, G. \& Wilkinson, D. (2002). The prevention of mental disorders in young people, Medical Journal of Australia, 177, S97-S100.

**Bakermans-Kranenburg, M.J., Van Ijzendoorn, M.H., \& Juffer, F. (2003) Less is more: meta-analyses of sensitivity and attachment interventions in early childhood. Psychological Bulletin, 129(2), 195-215.

Barlow J, Simpkiss D, Stewart-Brown S (Submitted). Interventions to prevent or ameliorate child physical abuse and neglect: Findings from a systematic review. Journal of Children's Services.

**Barlow, J \& Stewart-Brown, S. (2000). Behaviour problems and group-based parent education programs. Developmental and Behavioural Pediatrics, 21(3), 356-370.

**Barlow, J. \& Parsons, J. (2003). Group-based parent-training programmes for improving emotional and behavioural adjustment in 0-3 year old children. The Cochrane Database of Systematic Reviews, 2003, Issue 2. Art. No.: CD003680.DOI:10.1002/14651858.CD003680.

**Barlow, J., Shaw, R. \& Stewart-Brown, S. (2004). Parenting programmes and minority ethnic families. London: National Children's Bureau.

**Barlow, J., Parsons, J. \& Stewart-Brown, S. (2005). Preventing emotional and behavioural problems: the effectiveness of parenting programmes with children less than 3 years of age. Child: Care, Health and Development, 31(1), 33-42.

**Barnes, J. \& Freude-Lagevardi, A. (2003). From pregnancy to early childhood: early interventions to enhance the mental health of children and families. London: Mental Health Foundation.

**Bryant, D., Herndon-Vizzard, L., Willoughby, M. \& Kupersmidt, J. (1999). A review of interventions for preschoolers with aggressive and disruptive behavior. Early Education and Development, 10(1), 47-68.

Bull, J., McCormick, G., Swann, S. \& Mulvihill, C. (2004). Ante- and post-natal home-visiting programmes: a review of reviews. Health Development Agency: London.

${ }^{*}$ Cedar, B. \& Levant, R. (1990). A meta-analysis of the effects of parent effectiveness training. American Journal of Family Therapy, 18(4), 373384. 
Critical Appraisal Skills Programme. (2002).10 questions to help you make sense of reviews. Milton Keynes Primary Care Trust. [WWW] http://www.phru.nhs.uk. (Accessed 01/03/2005).

Department for Education and Skills. (2004). Every Child Matters: Change for Children. London: The Stationary Office.

Department of Health. (2004a) Choosing Health: making healthy choices easier. London: The Stationary Office.

Department of Health. (2004b). National Service Framework for Children, Young People and Maternity Services: Core Standards. London: The Stationary Office.

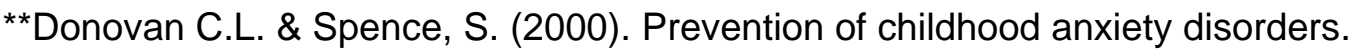
Clinical Psychology Review, 20(4), 509-531.

**Dubois, D.L., Holloway, B., Valentine, J.C. \& Cooper, H.(2002) Effectiveness of mentoring programs for youth: a meta-analytic review. American Journal of Community Psychology, 30(2), 157-97.

**Durlak, J. \& Wells, A. (1998). Evaluation of indicated preventive intervention (secondary prevention) mental health programs for children and adolescents. American Journal of Community Psychology, 26(5), 775-802.

**Durlak, J. \& Wells, A. (1997). Primary Prevention mental health programs for children and adolescents: a meta analytic review. American Journal of Community Psychology, 25(2), 115-52.

${ }^{\star *}$ Ekeland, E., Heian, F., Hagen, K.B., Abbott, J., \& Nordheim, L.(2004).Exercise to improve self-esteem in children and young people. The Cochrane Database of systematic reviews. Article number CD003683.pub2.DOI:10.1002/14651858.pub2..

**Haney, P. \& Durlak, J.A. Changing self-esteem in children and adolescents: a meta-analytic review. Journal of Clinical Child Psychology, 1998. 27(4), 423-433.

Henricson (2003). Government and Parenting: Is there a case for a policy review and a parents' code? York: Joseph Rowntree Foundation.

**Jané-Llopis, J., Hosman, C., Jenkins R. \& Anderson P. (2003). Predictors of efficacy in depression prevention programme. British Journal of Psychiatry, 183, 384-397. 
**Jane-Llopis E , Anderson P. (2005). Mental Health Promotion and Mental Disorder Prevention: a policy for Europe. Nijmegen: Radboud University, Nijmegen.

**Kulic, K.R., Dagley, J.\& Horne, A.M. (2004). A comprehensive review of prevention groups for children and adolescents. Group Dynamics: Theory, Research and Practice, 8(2), 139-51.

Lister-Sharp, D., Chapman, S., Stewart-Brown S. \& Sowden D. (1999). Health promoting schools and health promotion in schools: two systematic reviews. Health Technology Assessment, 3, (22)

**Losel, F. \& Beelman, A. (2003). Effects of child skills training in preventing antisocial behavior: a systematic review of randomised evaluations. Annals of the American Academy of Political and Social Science, 587, 84-109.

Meltzer H, Gatward R, Goodman R \& Ford T (2000). Mental Health of Children and Adolescent in Great Britain. The Stationery Officer, London, UK.

**Merry, S., McDowell, H., Hetrick S., Bir J. \& Muller N. (2004). Psychological and/or educational interventions for the prevention of depression in children and adolescents. Database: The Cochrane Database of systematic reviews, 2004. Article number: CD003380.pub2.DOI:10.1002/14651858.CD003380.pub2.

Moran, P., Ghate, D. \& van der Merwe, A.(2004). What works in parenting support? A review of the international evidence. London: Home Office/ Department for Education and Skills.

**Mytton, J.A., DiGuiseppe, C., Gough, D.A., Taylor R.S. \& Logan S. (2002). School-based violence prevention programmes. Archives of Pediatrics \& Adolescent Medicine, 156(8), 752-62.

**Nelson, G., Westhues, A. \& McLeod, J. (2003). A meta-analysis of longitudinal research on preschool prevention programs for children. Prevention \& Treatment, 6(31).

NHS Centre for Reviews and Dissemination. (1997). Mental health promotion in high risk groups. Effective Health Care, 3(3), 1-12. NHS Centre for Reviews and Dissemination: University of York. [WWW] http:// www.york.ac.uk/inst/crd/ehc33.htm (Accessed 01/03/05)

Nicholas, B. \& Broadstock, M. (1999). Effectiveness of early interventions for preventing mental illness in young people: a critical appraisal of the 
literature. 1999, Clearing House for Health Outcomes and Health Technology Assessment: Christchurch, New Zealand.

${ }^{\star *}$ Quinn, M. M, Kavale, K. A.,Mathur, S. R.,Rutherford, R B. \& Forness, S.R. (1999).A meta-analysis of social skill interventions for students with emotional or behavioural disorders. Journal of Emotional and Behavioural Disorders, 7(1), 54-64.

**Serketich, W.J. \& Dumans, J.E. (1996). The effectiveness of behavioural parent training to modify antisocial behaviour in children: a meta-analysis. Behaviour Therapy, 27, 171-186.

Tennant R, Goens C, Stewart-Brown S, Barlow J (2006). What works in mental health promotion and prevention for infants and children: a systematic review. Warwick: Univesity of Warwick.

van der Wolf, J.C. (1988). School effects: the use of planned intervention to study causal processes. In Rutter, M. (ed.) (1988b). Studies of psychosocial risk. Cambridge: Cambridge University Press.

**Wells, J., Barlow, J. \& Stewart-Brown, S. (2002). A systematic review of universal approaches to mental health promotion in schools. 2002, Health Services Research Unit: Oxford.

**Wilson, D.B., Gottfredson, D.C. \& Najaka, S.S. (2001). School-based prevention of problem behaviours: a meta-analysis. Journal of Quantitative Criminology, 2001. 17(3), 247-272.

World Health Organisation and Health Evidence Network (2006). What is the evidence on school health promotion in improving health or preventing disease and, specifically, what is the effectiveness of the health promoting schools approach. Geneva: World Health Organisation.

World Health Organisation (2005). Mental Health: facing the challenges, building the future. Geneva: World Health Organistion.

World Health Organisation Department of Mental Health and Substance Abuse in collaboration with the Prevention and Research Centre of the Universities of Nijmegen and Masstricht (2004). Prevention of Mental Disorders: effective interventions and policy options: summary report. Geneva: World Health Organistion.

World Health Organisation. (2002). Prevention and promotion in mental health. Geneva: World Health Organisation. 


\section{TABLE 1: SYSTEMATIC REVIEWS OF PARENTING PROGRAMMES}

\section{\begin{tabular}{l|l}
\hline TABLE 1: SYSTEMATIC REVIEWS OF PARENTIN \\
\hline Author/year & Barnes \& Freude-Lagevardi (2003) \\
\hline
\end{tabular}}

\begin{tabular}{l|l} 
Objectives & To review interventions to improve parenting, family functioning \& young children's mental health, including
\end{tabular}

the mechanisms that affect programme success

\begin{tabular}{l|l} 
Number \& type & $>90$ interventions (all review types, including case-reports)
\end{tabular}

of studies

\section{Bakermans-Kranenburg et al (2003)}

To assess whether early preventive interventions are effective in

enhancing parental sensitivity and infant attachment security

70 studies regardless of research design

\begin{tabular}{|c|c|c|}
\hline $\begin{array}{l}\text { Parent(s) or } \\
\text { children? }\end{array}$ & Parents and children & Children and parents \\
\hline Ethnicity & Not stated & Not stated \\
\hline \multicolumn{3}{|l|}{ Age } \\
\hline 0 to 6 & $\mathrm{X}(0-4)$ & Mean age $=54$ months \\
\hline \multicolumn{3}{|l|}{6 to 13} \\
\hline \multicolumn{3}{|c|}{\begin{tabular}{|l|l|}
13 to 19 & \\
\end{tabular}} \\
\hline \multicolumn{3}{|c|}{ INTERVENTIONS } \\
\hline \multicolumn{3}{|c|}{ Level of intervention } \\
\hline Universal & & Included middle class families and healthy infants \\
\hline Selective & $\begin{array}{l}\text { Majority of interventions targeted at disadvantaged/ high-risk populations. Also included reviews focusing on } \\
\text { abused/ neglected children, low-birth weight babies \& teenage parents }\end{array}$ & $\begin{array}{l}\text { Families from low socioeconomic status, adolescent mothers, } \\
\text { single parents and clinical and at-risk population were included } \\
\text { (prematurity, irritability and international adoption) }\end{array}$ \\
\hline \multicolumn{3}{|r|}{ (P) } \\
\hline $\begin{array}{l}\text { Type of } \\
\text { Intervention(s) }\end{array}$ & $\begin{array}{l}\text { - Any form of therapy or support service for families with infants or pre-school aged children } \\
\text { - Main intervention categories were home visiting, educational pre-school programmes, pre-natal \& } \\
\text { theoretically-driven programmes } \\
\text { Addresses the influence of programme model, programme target, intervenor, programme duration, timing } \\
\text { and intensity on outcomes }\end{array}$ & $\begin{array}{l}\text { Interventions aimed at enhancing positive parental behaviours in } \\
\text { four categories: } \\
\text { - } \quad \text { Sensitivity } \\
\text { - } \quad \text { Support } \\
\text { - } \quad \text { Representation } \\
\end{array}$ \\
\hline Results & $\begin{array}{l}\text { Participant characteristics } \\
\text { - Brief, hospital-based interventions such as the BNBAS-exam and minimal parent coaching may be } \\
\text { (cost)-effective in enhancing low-risk parents' knowledge, sensitivity and behaviour towards their infant } \\
\text { in the short-term. } \\
\text { - There is little evidence about which population groups benefit most from which interventions: } \\
\text { accumulation of risk factors may increase need, but not necessarily capacity to benefit } \\
\text { Although there is limited data to assess the impact of interventions on different population groups, first- } \\
\text { time mothers (including teenage mothers \& their infants) appear to benefit to a greater extent from early } \\
\text { intervention. }\end{array}$ & $\begin{array}{l}\text { Interventions focusing on sensitivity only were more effective } \\
(d=0.45) \text { than all other types of interventions combined }(d=0.27) \\
(p=0.03) \\
\text { Interventions with video feedback were more effective }(d=0.44) \\
\text { than interventions without videotape feedback }(d=0.31)(p=0.04) \\
\text { Interventions with fewer than } 5 \text { sessions were as effective } \\
(d=0.42) \text { as interventions with } 5 \text { to } 16 \text { sessions }(d=0.38) \text {. But } \\
\text { interventions with }>16 \text { sessions were less effective }(d=0.21) \text { than }\end{array}$ \\
\hline
\end{tabular}




\begin{tabular}{|c|c|c|}
\hline & $\begin{array}{l}\text { Programme types } \\
\text { - There is a growing evidence-base that ecological \& developmental models that address both the ecology } \\
\text { within which a child lives and the child's developmental stage are most likely to be effective } \\
\text { Multi-method interventions that combine multiple delivery formats, offer multiple therapeutic } \\
\text { approaches and have added services may have greater effect than single-method strategies } \\
\text { Group-base interventions appear to be a cost-effective alternative to individual therapy either in place of } \\
\text { or complementing individual therapy. } \\
\text { - Approaches that target both children and parents appear to be more effective than those that target } \\
\text { children or parents on their own, although some important effects can be seen in programmes targeting } \\
\text { parents only. } \\
\text { Theoretical approach of programmes } \\
\text { Few studies give a clear account of the theoretical basis of the programme, making it difficult to assess } \\
\text { the relative impact of different theoretical approaches. }\end{array}$ & $\begin{array}{l}\text { interventions with a smaller number of sessions }(p<0.001) \\
\text { Interventions starting at a later age were more effective }(d=0.44) \\
\text { than interventions starting prenatally }(d=0.32) \text { or in the first } 6 \\
\text { months }(d=0.28)(p=0.04) \\
\text { Interventions conducted at home }(d=0.29) \text { were not significantly } \\
\text { better than interventions conducted elsewhere }(d=0.48)\end{array}$ \\
\hline $\begin{array}{l}\text { Authors' } \\
\text { conclusion }\end{array}$ & $\begin{array}{l}\text { - May be more effective to target at-risk communities than specific families. } \\
\text { - } \quad \text { Early interventions likely to be most effective if they address both parent and child(ren). } \\
\text { - } \text { Attrition rates may be reduced by paying attention to specific barriers to participation and offering } \\
\text { incentives to attend (e.g. meals / free transport). } \\
\text { - No single programme or approach will be effective with all families: understanding a family's level of } \\
\text { risk \& developing a shared understanding of programme goals is crucial. } \\
\text { - High-risk families will benefit from health professionals and lay-workers working in parallel: lay } \\
\text { workers may be able to improve maternal emotional state but professional involvement is likely to be } \\
\text { required to achieve substantial improvements in parenting. } \\
\text { Interventions should ideally begin ante-natally: antenatal contact to work on primary engagement factors } \\
\text { (building trust, reducing practical barriers to participation) is likely to enhance subsequent involvement. } \\
\text { Minimal intervention (a few hours to a few days post-natally) appears to benefit low-risk populations and } \\
\text { may therefore be cost-effective. For vulnerable families, medium length interventions (up to } 12 \text { months) } \\
\text { appear to be more successful than either brief or extended ( }>1 \text { year) interventions. }\end{array}$ & $\begin{array}{l}\text { - Short interventions from RCTs focusing on sensitivity were } \\
\text { the most effective ( } d=0.47) \\
\text { Evidence shows that interventions with fewer contacts and } \\
\text { starting } 6 \text { months after birth or later are more effective } \\
\text { Interventions were effective in both high-risk families and } \\
\text { families with no identified risk }\end{array}$ \\
\hline $\begin{array}{l}\text { Reviewers' } \\
\text { conclusion }\end{array}$ & $\begin{array}{l}\text { - This is a reasonable quality review, which draws on a very wide range of study types, including case } \\
\text { reports of newer interventions that have not yet been the subject of formal trials. The review therefore } \\
\text { reflects current practice, although the evidence for some interventions is limited (and data on individual } \\
\text { programmes is only presented in a summary form). The review also includes comments from } \\
\text { practitioners about factors that are likely to affect the success of programmes. } \\
\text { - The review focuses more on the core principals of programme implementation than on the relative } \\
\text { effectiveness of different programmes. } \\
\text { This review should be regarded as representing up-to-date expert judgement and is likely to be } \\
\text { particularly useful for the information is contains on success factors. }\end{array}$ & $\begin{array}{l}\text { - This is a high-quality review, providing substantial evidence } \\
\text { from RCTs to support the conclusions reached by the authors } \\
\text { - Some of the results should be treated with caution due to the } \\
\text { fact that some of the above effect sizes were obtained for a } \\
\text { very small number of studies } \\
\text { - The evidence for the effectiveness of attachment } \\
\text { interventions for multi-risk families is inconclusive }\end{array}$ \\
\hline $\begin{array}{l}\text { Quality } \\
\text { Score }\end{array}$ & 10 & 12 \\
\hline
\end{tabular}




\begin{tabular}{|c|c|c|}
\hline \multicolumn{3}{|c|}{ TABLE 1: SYSTEMATIC REVIEWS OF PARENTING PROGRAMMES (continued) } \\
\hline Author/year & Barlow \& Stewart-Brown (2000) & Barlow J et al (2002) \\
\hline Objectives & $\begin{array}{l}\text { To evaluate the effectiveness of group-based parent education programmes aimed at } \\
\text { improving behaviour problems in } 3 \text { to10-year-old children }\end{array}$ & $\begin{array}{l}\text { To evaluate the effectiveness of group-based parenting programmes in improving the } \\
\text { psychosocial health of mothers }\end{array}$ \\
\hline $\begin{array}{l}\text { Number \& type } \\
\text { of studies } \\
\text { included }\end{array}$ & 16 RCTs & 22 RCTs \\
\hline \multicolumn{3}{|l|}{ PARTICIPANTS } \\
\hline $\begin{array}{l}\text { Parent(s) or } \\
\text { children? }\end{array}$ & Parents & Parents \\
\hline Ethnicity & Not stated & Majority Caucasian \\
\hline \multicolumn{3}{|c|}{ Age of participants } \\
\hline 0 to 6 & 3 to 10 & Parents of children between 0 to 8 years \\
\hline 6 to 13 & 3 to 10 & Parents of children between 0 to 8 years \\
\hline \multicolumn{3}{|r|}{ 然 } \\
\hline \multicolumn{3}{|c|}{ INTERVENTIONS } \\
\hline \multicolumn{3}{|c|}{ Level of intervention } \\
\hline Universal & & Parents of children between 0 to 8 years \\
\hline Selective & & Parents of children with ADHD \\
\hline Indicated & $\begin{array}{l}\text { Participants had defined behaviour problems including at least one externalizing } \\
\text { problem (e.g., temper tantrums, aggression, non-compliance) }\end{array}$ & \\
\hline $\begin{array}{l}\text { Type of } \\
\text { Intervention(s) }\end{array}$ & $\begin{array}{l}\text { Group-based programmes with a standardized format aimed at enhancing parenting } \\
\text { skills }\end{array}$ & $\begin{array}{l}\text { categories of programme based on different theoretical approaches: } \\
\text { - } \quad \text { Behavioural } \\
\text { - } \quad \text { Multi-modal } \\
\text { - } \quad \text { Behavioural and Humanistic } \\
\text { - } \quad \text { Rational-emotive therapy programmes } \\
\end{array}$ \\
\hline Results & $\begin{array}{l}\text { All outcomes - parents' reports of children's behaviour } \\
\text { Effect sizes ranged from } 0.6 \text { to } 2.9 \text { in favour of the intervention group } \\
\text { All outcomes - independent observation of children's behaviour } \\
\text { Effect sizes ranged from } 0.2 \text { to } 0.4 \text { in favour of the intervention group }\end{array}$ & $\begin{array}{l}\frac{\text { Maternal depression }}{d=-0.26 \text { (CI: }-0.42 \text { to } 0.11) \text { in favour of intervention group }} \\
\frac{\text { Maternal anxiety/stress }}{d=-0.5(\text { CI: }-0.71 \text { to }-0.29)} \text { in favour of intervention group }\end{array}$ \\
\hline
\end{tabular}




\begin{tabular}{|c|c|c|}
\hline & & $\begin{array}{l}\frac{\text { Maternal self esteem }}{d=-0.35 \text { (CI: }-0.6 \text { to }-0.09)} \text { in favour of intervention group } \\
\frac{\text { Relationship with partner }}{d=-0.43 \text { (CI:-0.71, }-0.15 \text { ) in favour of intervention group }}\end{array}$ \\
\hline $\begin{array}{l}\text { Author's } \\
\text { conclusions }\end{array}$ & $\begin{array}{l}\text { - } \quad \text { Group-based parent education programmes are effective in producing changes in } \\
\text { both parental perceptions and objective measures of children's behaviour } \\
\text { - } \quad \text { Some evidence to suggest that these changes are maintained over time } \\
\text { - Caution should be exercised before the findings of this review are generalized } \\
\text { broadly, because of the small number of studies for which effect sizes could be } \\
\text { calculated }\end{array}$ & $\begin{array}{l}\text { - Parenting programmes may be effective in the short-term in improving maternal } \\
\text { depression, anxiety/stress, self-esteem and the mother's relationship with her } \\
\text { partner } \\
\text { - Only the changes in self-esteem were maintained at follow-up, but this finding is in } \\
\text { part due to the limited amount of follow-up data available } \\
\text { - None of the included studies carried out intention-to-treat analyses }\end{array}$ \\
\hline $\begin{array}{l}\text { Reviewer's } \\
\text { conclusions }\end{array}$ & $\begin{array}{l}\text { - This is a good quality review and provides evidence supporting the effectiveness } \\
\text { of group-based parenting programmes in changing children's behaviour }\end{array}$ & $\begin{array}{l}\text { - This is a high quality review and provides substantial evidence to support the use of } \\
\text { parent education programmes to improve maternal psychosocial health }\end{array}$ \\
\hline Quality score & 12 & 16 \\
\hline
\end{tabular}




\begin{tabular}{|c|c|c|c|c|}
\hline Author/year & Barlow et al. (2004) & Barlow J. et al (2003) & Cedar \& Levant (1990) & Serketich \& Dumas (1996) \\
\hline Objectives & $\begin{array}{l}\text { To describe the experiences of minority ethnic } \\
\text { families taking part in parenting programmes } \\
\text { To address whether parenting programmes are more } \\
\text { effective with some ethnic groups than others and } \\
\text { whether culturally sensitive programmes are more } \\
\text { effective than traditional parenting programmes }\end{array}$ & $\begin{array}{l}\text { To establish whether group-based parenting } \\
\text { programmes are effective in improving the } \\
\text { emotional and behavioural adjustment of } \\
\text { children less than } 3 \text { years of age }\end{array}$ & $\begin{array}{l}\text { To evaluate whether Parent } \\
\text { Effectiveness Training (PET) is an } \\
\text { effective preventive intervention }\end{array}$ & $\begin{array}{l}\text { To evaluate the effectiveness of } \\
\text { Behavioural Parent Training } \\
\text { programmes in modifying } \\
\text { antisocial behaviour in children at } \\
\text { home and school }\end{array}$ \\
\hline $\begin{array}{l}\text { Number \& type } \\
\text { of studies } \\
\text { included }\end{array}$ & $\begin{array}{l}39 \text { quantitative (RCTs, controlled/ comparative, one } \\
\text { group \& retrospective studies); } 12 \text { qualitative studies }\end{array}$ & 5 RCTs & $\begin{array}{l}26 \text { studies - all two-group designs } \\
\text { with pre- and post-treatment } \\
\text { measurement }\end{array}$ & 26 controlled studies (8 RCT) \\
\hline \multicolumn{5}{|l|}{ PARTICIPANTS } \\
\hline $\begin{array}{l}\text { Parent(s) or } \\
\text { children? }\end{array}$ & Parents \& children & Parents & Parents & Parents \\
\hline Ethnicity & $\begin{array}{l}\text { Black parents (20 studies) } \\
\text { Hispanic parents ( } 8 \text { studies) } \\
\text { Native Americans ( } 2 \text { studies) }\end{array}$ & 2 studies included multi-ethnic parents & Not stated & Not stated \\
\hline \multicolumn{5}{|c|}{ Age of participants } \\
\hline 0 to 6 & $\mathrm{X}$ & Parents of children aged 3 or less & $\mathrm{X}$ & Under 6 \\
\hline 6 to 13 & $\mathrm{X}$ & & $\mathrm{X}$ & $6-14$ \\
\hline 13 to 19 & & & & \\
\hline \multicolumn{5}{|c|}{ INTERVENTIONS } \\
\hline \multicolumn{5}{|c|}{ Level of intervention } \\
\hline Universal & $\mathrm{X}$ & Population sample & & \\
\hline Selective & $\mathrm{X}$ & $\begin{array}{l}\text { Parents of toddlers in day-care low-income } \\
\text { communities } \\
1 \text { programme was directed at parents using } \\
\text { harsh parenting strategies }\end{array}$ & $\mathrm{X}$ & $\begin{array}{l}\text { Children displaying antisocial } \\
\text { behaviour }\end{array}$ \\
\hline Indicated & $\mathrm{X}$ & & & \\
\hline $\begin{array}{l}\text { Type of } \\
\text { Intervention(s) }\end{array}$ & $\begin{array}{ll}\text { Group-based parenting programmes categorised as: } \\
\text { - } \quad \text { Traditional }(n=18) \\
\text { - } \quad \text { Translated }(n=4) \\
\text { - } \quad \text { Adapted }(n=7) \\
\text { Culturally-specific }(n=7)\end{array}$ & $\begin{array}{l}\text { Group-based parenting programmes: } \\
\text { Videotape modelling, cognitive-behavioural } \\
\text { parenting programmes, behavioural parenting } \\
\text { training, and small group-based cognitive- } \\
\text { behavioural parenting programme for parents at } \\
\text { risk of using harsh parenting strategies. }\end{array}$ & $\begin{array}{l}\text { Parent Effectiveness Training is an } \\
8 \text { session structured self-help } \\
\text { intervention, which aims to alter } \\
\text { ineffective communication patterns } \\
\text { that rely on negative emotions } \\
\text { between parent and child. }\end{array}$ & $\begin{array}{l}\text { Behavioural Parent Training } \\
\text { (BPT): } \\
\text { Training of parents/caregivers in } \\
\text { the use of differential } \\
\text { reinforcement and/or time-out } \\
\text { procedure. Studies were included if }\end{array}$ \\
\hline
\end{tabular}




\begin{tabular}{|c|c|c|c|c|}
\hline & & & & $\begin{array}{l}\text { these were combined with the use } \\
\text { of other therapeutic techniques. }\end{array}$ \\
\hline Results & $\begin{array}{l}\text { Overall effectiveness of parenting programmes } \\
\text { Black Families } \\
\text { The } 6 \text { most reliable studies showed a range of } \\
\text { positive outcomes } \\
\text { Two small studies produced negative results, } 4 \\
\text { larger studies showed effectiveness for } \\
\text { traditional, translated \& culturally-specific } \\
\text { programmes (improvements in both parent \& } \\
\text { independent assessment of children's emotional } \\
\text { \& behavioural adjustment, intellectual } \\
\text { development, problem-solving ability \& play, } \\
\text { parenting attitudes \& behaviour (including use of } \\
\text { harsh/ inconsistent discipline) } \\
\text { All studies showed evidence of no effect for } \\
\text { some outcomes } \\
\text { Ethnically-mixed programmes } \\
\text { In the } 2 \text { studies that used a control group, there } \\
\text { was evidence of some improvement in children's } \\
\text { emotional \& behavioural adjustment \& learning } \\
\text { problems } \\
\text { There was also evidence of some improvement } \\
\text { in parenting attitudes \& behaviour, including } \\
\text { levels of verbal \& corporal punishment, anger \& } \\
\text { stress } \\
\text { Relative effectiveness of parenting programmes with } \\
\text { different ethnic groups } \\
\text { In one study, white parents reported negligible } \\
\text { outcomes for child conduct and social } \\
\text { competence and black parents reported } \\
\text { negligible improvement in social competence but } \\
\text { not child conduct } \\
\text { Independent observation of child behaviour } \\
\text { showed moderate improvements in conduct and } \\
\text { measures of deviance, but negligible } \\
\text { improvement in positive affect. African- } \\
\text { American children showed small improvements }\end{array}$ & 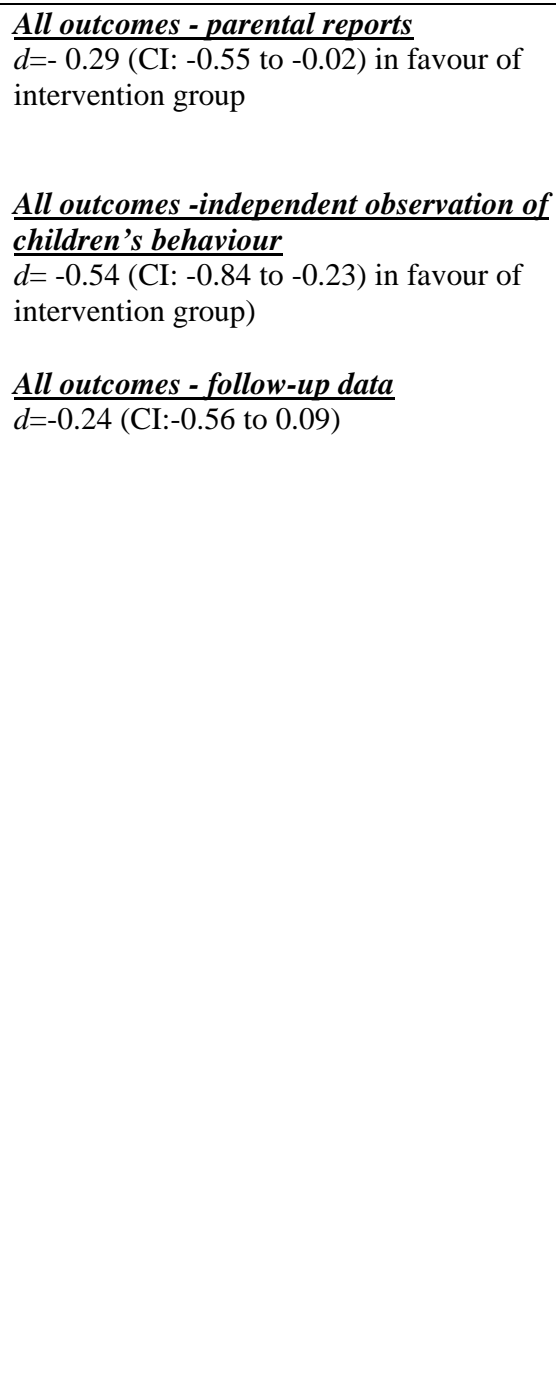 & $\begin{array}{l}\frac{\text { Overall mean effect size of PET }}{d=0.33} \\
\frac{\text { Parents' course knowledge }}{d=1.10} \\
\frac{\text { Parental attitudes (towards }}{\text { parenting) }} d=0.41 \\
\frac{\text { Parental behaviour (towards }}{\frac{\text { children) }}{d=0.37}} \\
\frac{\text { Child self-esteem }}{d=0.38} \\
\frac{\text { Child attitudes }}{d=0.12} \\
\frac{\text { Child behaviour }}{d=0.03}\end{array}$ & $\begin{array}{l}\frac{\text { Overall child outcome }}{d=0.86} \\
\frac{\text { Child outcome (parental report) }}{d=0.84} \\
\frac{\text { Child outcome (observer report) }}{d=0.85} \\
\frac{\text { Teacher report }}{d=0.73} \\
\frac{\text { Parental adjustment }}{d=0.44}\end{array}$ \\
\hline
\end{tabular}




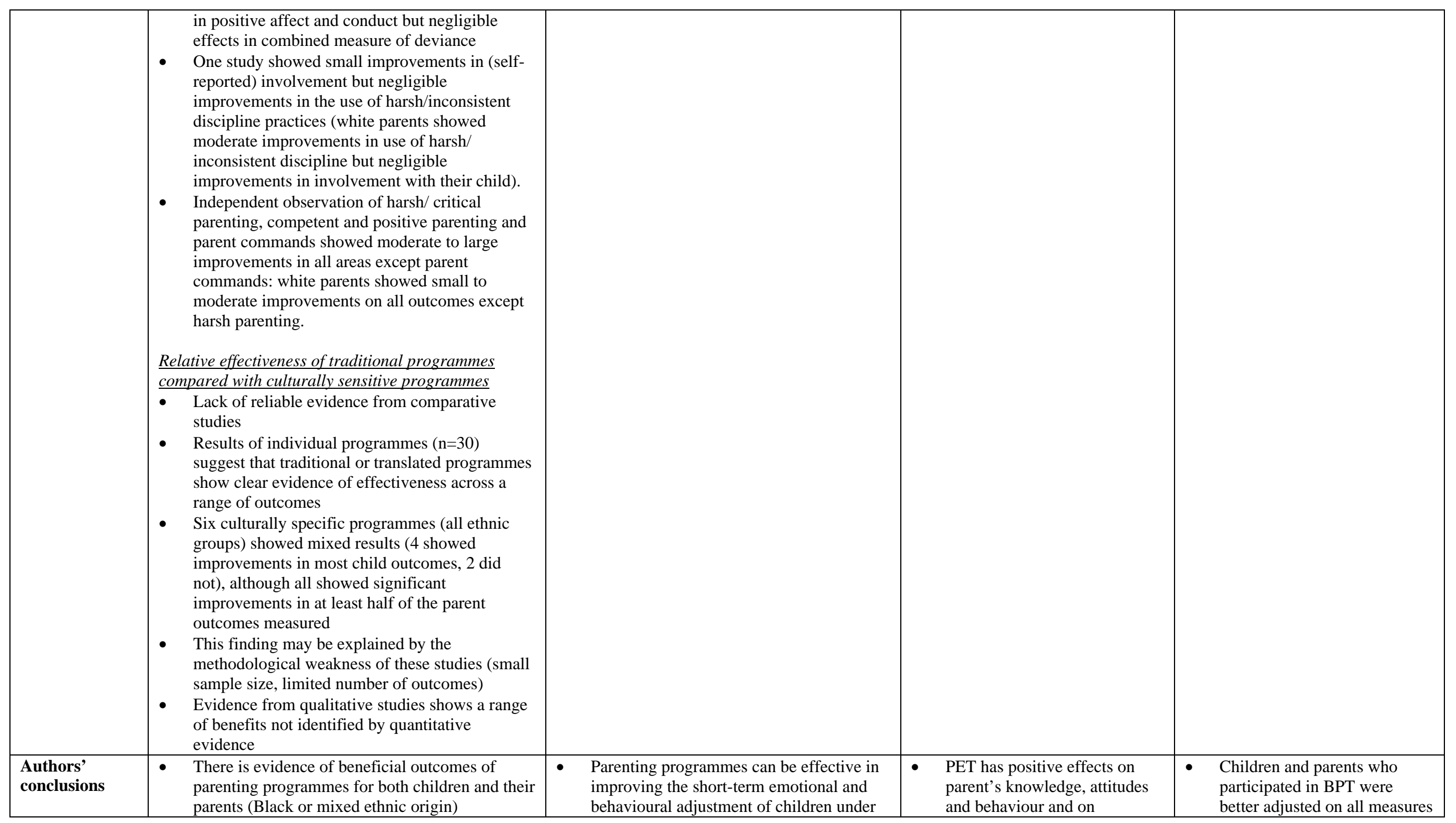




\begin{tabular}{|c|c|c|c|c|}
\hline & $\begin{array}{l}\text { There is little high-quality evidence to support } \\
\text { the view that culturally-specific programmes are } \\
\text { more effective than traditional programmes. } \\
\text { However, this finding may be due to the lack of } \\
\text { good quality comparative studies } \\
\text { Qualitative reviews point to the 'added benefits' } \\
\text { of culturally specific programmes in enhancing } \\
\text { and extending parents' knowledge about their } \\
\text { culture and the role that this may play in } \\
\text { influencing parenting practices }\end{array}$ & $\begin{array}{l}\text { the age of } 3 \text { years } \\
\text { The findings support the use of group- } \\
\text { based parenting programmes to improve } \\
\text { the emotional and behavioural adjustment } \\
\text { of children under the age of } 3 \text { years }\end{array}$ & $\begin{array}{l}\text { children's self esteem } \\
\text { These effects endured (up to } 26 \\
\text { weeks) after the programmes } \\
\text { were completed }\end{array}$ & $\begin{array}{l}\text { of functioning than children } \\
\text { and parents who did not. } \\
\text { No reliable conclusions can be } \\
\text { drawn about BPT's } \\
\text { effectiveness in modifying } \\
\text { antisocial behaviour relative to } \\
\text { the effectiveness of other } \\
\text { treatments. }\end{array}$ \\
\hline $\begin{array}{l}\text { Reviewer's } \\
\text { conclusions }\end{array}$ & $\begin{array}{l}\text { - This is a high quality review that draws on } \\
\text { predominantly controlled studies and uses } \\
\text { qualitative data to complement the findings of } \\
\text { quantitative studies. } \\
\text { The conclusions should be regarded as a robust } \\
\text { summary of the current research evidence in this } \\
\text { area. }\end{array}$ & $\begin{array}{l}\text { This was a high quality review supporting } \\
\text { the use of parenting programmes to } \\
\text { improve outcomes in children under the } \\
\text { age of } 3 \text { years }\end{array}$ & $\begin{array}{l}\text { This was a medium quality } \\
\text { review due in part to the } \\
\text { inclusion of a range of study } \\
\text { designs. The results should } \\
\text { therefore be treated with } \\
\text { caution } \\
\text { No conclusions can be drawn } \\
\text { about the effectiveness of PET } \\
\text { relative to other types of parent } \\
\text { training programme. }\end{array}$ & $\begin{array}{l}\text { This was a medium-quality } \\
\text { review due in part to the lack } \\
\text { of information provided about } \\
\text { included studies. } \\
\text { It provides some evidence to } \\
\text { support the effectiveness of } \\
\text { BPT to improve child } \\
\text { antisocial behaviour but the } \\
\text { results should be treated with } \\
\text { some caution. }\end{array}$ \\
\hline Quality score & 13 & 15 & 8 & 9 \\
\hline
\end{tabular}




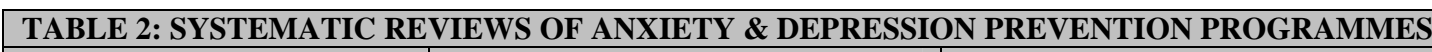

\begin{tabular}{|c|c|c|}
\hline Author/year & Andrews \& Wilkinson (2002) & Jane-Llopis et al. (2003) \\
\hline Objectives & $\begin{array}{l}\text { To establish the value of risk-factor } \\
\text { reduction or enhanced coping } \\
\text { strategies in preventing the onset of } \\
\text { anxiety, affective or substance-use } \\
\text { disorders }\end{array}$ & To identify potential predicators of outcome in prevention programmes \\
\hline Number \& type of studies & 20 RCTs & 54 RCTs/ controlled trials \\
\hline \multicolumn{3}{|l|}{ PARTICIPANTS } \\
\hline Parent(s) or children? & Children and adolescents & Children and adolescents \\
\hline Ethnicity & - & Mixed \\
\hline \multicolumn{3}{|l|}{ Age of participants } \\
\hline 0 to 6 & $\mathrm{X}$ & $\mathrm{X}$ \\
\hline 6 to 13 & $\mathrm{X}$ & $\mathrm{X}$ \\
\hline 13 to 19 & Young people under 19 & $\mathrm{X}$ \\
\hline \multicolumn{3}{|l|}{ INTERVENTIONS } \\
\hline \multicolumn{3}{|l|}{ Level of intervention } \\
\hline Universal & $\mathrm{X}$ & $\mathrm{X}$ \\
\hline Selected & $\mathrm{X}$ & $\mathrm{X}$ \\
\hline Indicated & & $\mathrm{X}$ \\
\hline $\begin{array}{l}\text { Type of } \\
\text { Intervention(s) }\end{array}$ & $\begin{array}{l}\text { Predominantly cognitive behavioural } \\
\text { therapy interventions, delivered by } \\
\text { teachers, clinicians or psychologists }\end{array}$ & $\begin{array}{l}\text { 5 broad categories of intervention: } \\
\text { - Behavioural (behaviour change, modelling) } \\
\text { - Cognitive (cognitive restructuring, counselling, explanatory style } \\
\text { training) } \\
\text { - Competence-based (broad skill training, social resistance skills) } \\
\text { - Educational (direct instruction, lectures \& workshops) } \\
\text { - Social support (network building, fostering socialisation) }\end{array}$ \\
\hline Results & $\begin{array}{l}\text { CBT to prevent depressive disorders } \\
\text { may be effective in both universal } \\
\text { and targeted groups }\end{array}$ & $\begin{array}{l}\text { All outcomes } \\
\text { Children }(0-14 \mathrm{yrs})(\mathrm{n}=16) \\
d=0.21 \text { (CI: } 0.09 \text { to } 0.32)\end{array}$ \\
\hline
\end{tabular}

\section{Merry et. al (2004)}

To determine whether psychological and/ or educational interventions targeted) are effective in preventing or treating depressive disorders

\section{RCTs}

\section{Children and adolescents}

Not stated

From 5 years

$\mathrm{X}$

$\mathrm{X}$

$\mathrm{X}$

Psychological interventions: 18 studies using cognitive behavio to combat stress, build resilience or improve problem solving ski programmes, 8 targeted programmes for young people with elev scores)

- Educational intervention: 1 study (using three 50-minute manua

Psycho-educational: 2 studies (16-session intervention to studen depression scores, given by psychologists/clinically trained grad session programme to children whose parents had separated)

Psychological interventions vs. non-intervention (immediately post-i Depression scores

$d=-0.26$ (CI: -0.40 to -0.13 ) in favour of intervention 


\begin{tabular}{|c|c|c|c|}
\hline & $\begin{array}{l}\text { and in preventing anxiety disorders in } \\
\text { children identified as being at risk }\end{array}$ & $\begin{array}{l}\text { Adolescents }(15-18 \mathrm{yrs})(\mathrm{n}=9) \\
d=0.19 \text { (CI: } 0.007 \text { to } 0.38) \\
\text { All ages (adults included) } \\
d=0.22 \text { (CI: } 0.14-0.30) \\
\text { Programmes with larger effect sizes were: } \\
\text { - multi-component } \\
\text { - included competence techniques } \\
\text { - had more than } 8 \text { sessions } \\
\text { - wad sessions } 60-90 \text { minutes long }\end{array}$ & $\begin{array}{l}\text { Targeted vs. universal (immediately post-intervention) } \\
\text { Depression scores (SMD) } \\
\text { Targeted interventions } \\
d=-0.26 \text { (CI: }-0.40 \text { to }-0.13 \text { ) } \\
\text { Universal interventions } \\
d=-0.21 \text { (CI: }-0.48 \text { to } 0.06) \\
\text { All interventions } \\
d=-0.26 \text { (CI: }-0.36 \text { to }-0.15 \text { ) } \\
\text { Pooled data showed no significant effect for either universal or target } \\
\text { at any other time point, except at } 36 \text { months for } 1 \text { study } d=-0.29 \text { (CI: } \\
\text { Depression diagnosis (Risk Difference) } \\
\text { Targeted (n=3) } \\
R D=-0.13 \text { (CI: }-0.22 \text { to }-0.05 \text { ) } \\
\text { Universal (n=2) } \\
R D=-0.08 \text { (CI: }-0.15 \text { to }-0.01 \text { ) } \\
\text { Both (n=5) } \\
R D=-0.10 \text { (CI: }-0.15 \text { to }-0.05 \text { ) } \\
\text { Pooling targeted and universal interventions at } 12 \text { months showed no } \\
\text { Although at } 12 \text { months } 2 \text { studies of targeted interventions reported a d } \\
\text { diagnosis of depressive disorder RD }-0.12, \text { (CI }-0.24 \text { to }-0.01 \text { ). } \\
\text { Educational vs. psychological } \\
\text { No evidence of the effectiveness of educational interventions. Compa } \\
\text { available }\end{array}$ \\
\hline Author's conclusions & $\begin{array}{l}\text { Evidence that some anxiety, } \\
\text { affective and substance-use } \\
\text { disorders can be prevented. } \\
\text { Trials show that interventions are } \\
\text { efficacious but there is limited } \\
\text { evidence about effectiveness in } \\
\text { routine practice }\end{array}$ & $\begin{array}{l}\text { An } 11 \% \text { improvement in depressive symptoms can be achieved using } \\
\text { prevention programmes }\end{array}$ & $\begin{array}{l}\text { - There is insufficient evidence to merit the introduction of depres } \\
\text { programmes although results suggest that further study would be } \\
\text { - Most studies have focused on psychological interventions and th } \\
\text { educational interventions has not been fully investigated }\end{array}$ \\
\hline Reviewer's conclusions & $\begin{array}{l}\text { This is a poor quality review that } \\
\text { does not appear to have used a } \\
\text { systematic search }\end{array}$ & $\begin{array}{l}\text { - This review points to moderate effects of depression prevention } \\
\text { programmes across all outcomes (combined) } \\
\text { - } \quad \text { Results should be interpreted with caution due to the relatively }\end{array}$ & $\begin{array}{l}\text { - This is a methodologically sound Cochrane review that draws on } \\
\text { The conclusions drawn reached by the authors are therefore likel }\end{array}$ \\
\hline
\end{tabular}




\begin{tabular}{|c|c|c|c|}
\hline & $\begin{array}{l}\text { - The review identifies a number } \\
\text { of successful programmes but } \\
\text { the serious design flaws in the } \\
\text { study mean that its conclusions } \\
\text { should be treated with caution }\end{array}$ & low quality of the review & \\
\hline $\begin{array}{l}\text { Quality } \\
\text { Score }\end{array}$ & 5 & 9 & 15 \\
\hline
\end{tabular}




\begin{tabular}{|c|c|c|}
\hline \multicolumn{3}{|c|}{ TABLE 3: SYSTEMATIC REVIEWS OF SELF-ESTEEM PROGRAMMES } \\
\hline Author/year & Ekeland et al (2004) & Haney \& Durlak (1998) \\
\hline Objectives & $\begin{array}{l}\text { To evaluate whether exercise (alone or as part of a comprehensive intervention) can } \\
\text { improve self-esteem among children and young people }\end{array}$ & $\begin{array}{l}\text { To assess whether self-esteem interventions for children } \& \text { adolescents is effective in improving } \\
\text { self-esteem and self-confidence and to identify whether these changes are associated with other } \\
\text { behavioural, academic or social outcomes }\end{array}$ \\
\hline $\begin{array}{l}\text { Number and } \\
\text { type of studies }\end{array}$ & 23 randomized/ “quasi-randomized” controlled trials & $\begin{array}{l}102 \text { studies that included some type of control group (either attention-placebo or no treatment) } \\
\text { drawn from the same population as the intervention group }\end{array}$ \\
\hline \multicolumn{3}{|r|}{ ( } \\
\hline $\begin{array}{l}\text { Parent(s) or } \\
\text { children? }\end{array}$ & Young people & Children or adolescents \\
\hline Ethnicity & Not stated & $\begin{array}{l}\text { Caucasian or mostly Caucasian: } 19 \% \\
\text { Minority or mostly minority: } 16 \% \\
\text { Mixed: } 3 \% \\
\text { Unknown: } 62 \% \\
\end{array}$ \\
\hline \multicolumn{3}{|c|}{ Age of participants } \\
\hline 0 to 6 & 3 to 20 years & $\mathrm{X}$ \\
\hline 6 to 13 & $\mathrm{X}$ & $\mathrm{X}$ \\
\hline 13 to 19 & 3 to 20 years & Mean age of 18 or younger \\
\hline \multicolumn{3}{|c|}{ INTERVENTIONS } \\
\hline \multicolumn{3}{|c|}{ Level of intervention } \\
\hline Universal & Healthy children & Youth without presenting problems (internalizing, externalising, mixed problems). \\
\hline Indicated & $\begin{array}{l}\text { Children with learning disabilities and/or emotional disturbances, children with low } \\
\text { self-image, children with deficits in gross motor skills and young offenders }\end{array}$ & Youth with presenting problems (internalizing, externalising, mixed problems) \\
\hline $\begin{array}{l}\text { Type of } \\
\text { Intervention(s) }\end{array}$ & $\begin{array}{l}\text { The interventions lasted between } 4 \text { and } 20 \text { weeks and included aerobic programmes, } \\
\text { strength training programmes, skills training and a combination of these. } \\
\text { Some interventions combined the exercise with counselling, skills training and } \\
\text { social activities, others focused on exercise alone. }\end{array}$ & $\begin{array}{l}\text { SE/ SC interventions included commercially available programmes using combined techniques (role } \\
\text { playing, affective education, parent training, behavioural modification, communication \& social } \\
\text { skills training). } \\
\text { Non-SE/SC studies included group counselling, relaxation training, tutoring, CBT, play therapy, } \\
\text { teacher consultation and problem-solving training. }\end{array}$ \\
\hline
\end{tabular}




\begin{tabular}{|c|c|c|}
\hline Results & $\begin{array}{l}\text { Exercise only vs No intervention: } \\
\text { Global self-esteem } \\
\text { All children } \\
d=0.49 \text { (CI: } 0.16 \text { to } 0.81 \text { ) (in favour of the exercise intervention) } \\
\text { Healthy children } \\
d=0.53 \text { (CI: }-0.04 \text { to } 1.09) \\
\text { Children at risk/ with defined problems } \\
d=0.49 \text { (CI: } 0.17 \text { to } 0.82) \\
\text { Exercise as part of a comprehensive intervention vs No intervention: } \\
\text { Global self-esteem score } \\
\text { All children } \\
d=0.51 \text { (CI: } 0.15 \text { to } 0.88 \text { ) }\end{array}$ & 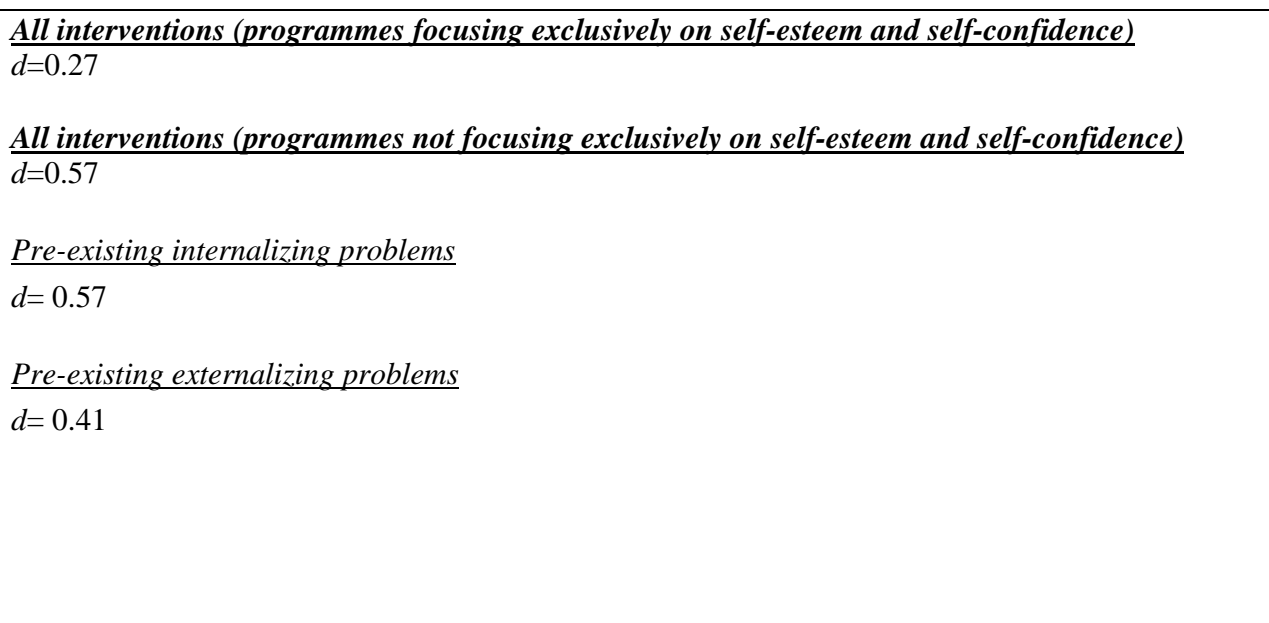 \\
\hline $\begin{array}{l}\text { Authors' } \\
\text { Conclusions }\end{array}$ & $\begin{array}{l}\text { Exercise has positive short-term effects on self-esteem in children and young } \\
\text { people } \\
\text { Programmes that included only exercise showed similar effects to programmes } \\
\text { that included exercise as part of a wider programme. However, these results } \\
\text { need to be interpreted with caution as interventions that included exercise as } \\
\text { part of a wider programme covered a broad range of very different types of } \\
\text { intervention }\end{array}$ & $\begin{array}{l}\text { - Improving children and adolescent self esteem and/ or self-confidence can be achieved } \\
\text { - } \quad \text { Programmes that specifically focus on SE/SC are more likely to be effective than interventions } \\
\text { that target other goals } \\
\text { - } \quad \text { Programmes appear to be more effective with children and adolescents with presenting } \\
\text { problems, particularly those with internalising problems }\end{array}$ \\
\hline $\begin{array}{l}\text { Reviewers' } \\
\text { conclusions }\end{array}$ & $\begin{array}{l}\text { - This is a high quality review, which included only randomised and quasi- } \\
\text { randomised controlled trials } \\
\text { As the authors note, the conclusions are based on a small number of trials and } \\
\text { the results should therefore be treated with caution }\end{array}$ & $\begin{array}{l}\text { - This is a moderate quality review: the reliability of the findings may be compromised because } \\
\text { non-randomised trials were included }\end{array}$ \\
\hline $\begin{array}{l}\text { Quality } \\
\text { Score }\end{array}$ & $\begin{array}{ll}14 \\
\end{array}$ & 8 \\
\hline
\end{tabular}




\begin{tabular}{|c|c|c|c|c|c|c|}
\hline Author/year & Bryant et al (1999) & $\begin{array}{l}\text { Farrington\& Welsh } \\
(2003)\end{array}$ & $\begin{array}{l}\text { Losel \& Beelmann } \\
(2003)\end{array}$ & Mytton et al (2002) & Quinn et al (1999) & Wilson et al. (2003) \\
\hline Objectives & $\begin{array}{l}\text { To evaluate the efficacy of } \\
\text { prevention programmes for } \\
\text { aggressive behaviour among } \\
\text { preschoolers with otherwise normal } \\
\text { development }\end{array}$ & $\begin{array}{l}\text { To evaluate the } \\
\text { effectiveness of family- } \\
\text { based prevention } \\
\text { programmes in reducing } \\
\text { offending and antisocial } \\
\text { behaviour in children and } \\
\text { adolescents }\end{array}$ & $\begin{array}{l}\text { To evaluate the } \\
\text { effectiveness of child } \\
\text { skills training in } \\
\text { preventing antisocial } \\
\text { behaviour in children and } \\
\text { youth }\end{array}$ & $\begin{array}{l}\text { To quantify the effectiveness of } \\
\text { school-based violence } \\
\text { prevention programmes for } \\
\text { children identified as at risk for } \\
\text { aggressive behaviour }\end{array}$ & $\begin{array}{l}\text { To assess the effect of } \\
\text { social-skills training for } \\
\text { students with emotional } \\
\text { or behavioural disorders }\end{array}$ & $\begin{array}{l}\text { To assess the effectiveness of } \\
\text { mainstream service programmes } \\
\text { for minority juvenile delinquents } \\
\text { relative to White delinquents }\end{array}$ \\
\hline $\begin{array}{l}\text { Number \& } \\
\text { type of studies }\end{array}$ & 17 studies (any design) & 40 studies, mostly RCTs & 84 RCTs & 44 RCTs & 35 studies & $\begin{array}{l}305 \text { studies with an experimental } \\
\text { or quasi experimental } \\
\text { comparison of at least one } \\
\text { treatment and one control group }\end{array}$ \\
\hline \multicolumn{7}{|c|}{ PARTICIPANTS } \\
\hline $\begin{array}{l}\text { Parent(s) or } \\
\text { children? }\end{array}$ & $\begin{array}{l}\text { Preschool aged children and also } \\
\text { parents of preschoolers }\end{array}$ & Parents and children & Children and youth & Children & Children & Youth \\
\hline Ethnicity & $\begin{array}{l}\text { Predominantly White } \\
2 \text { studies included ethnic minority } \\
\text { families }\end{array}$ & Not stated & Not stated & Not stated & Not stated & $\begin{array}{l}\text { Youth from ethnic minority } \\
\text { groups }\end{array}$ \\
\hline \multicolumn{7}{|c|}{ Age of participants } \\
\hline 0 to 6 & $\mathrm{X}$ & $\mathrm{X}$ & $\mathrm{X}$ & & & \\
\hline 6 to 13 & Up to 8 years & $\mathrm{X}$ & $\mathrm{X}$ & $\mathrm{X}$ & $\begin{array}{l}\text { Average age of } \\
\text { participants: } 11.5 \text { years }\end{array}$ & 12 to 21 \\
\hline 13 to 19 & & Up to 17 years & Up to 18 years & Up to 18 & & 12 to 21 \\
\hline \multicolumn{7}{|c|}{ INTERVENTIONS } \\
\hline \multicolumn{7}{|c|}{ Level of intervention } \\
\hline Universal & & $\mathrm{X}$ & $\mathrm{X}$ & & & \\
\hline Selective & $\begin{array}{l}2 \text { studies included many low- } \\
\text { income families }\end{array}$ & $\begin{array}{l}\text { Children that belong to } \\
\text { families with risk factors. }\end{array}$ & $\mathrm{X}$ & $\begin{array}{l}\text { Children at risk of aggressive } \\
\text { behaviour. }\end{array}$ & & \\
\hline Indicated & $\begin{array}{l}\text { Preschoolers with aggressive and } \\
\text { disruptive behaviour. }\end{array}$ & $\mathrm{X}$ & $\mathrm{X}$ & & $\begin{array}{l}\text { Children with emotional } \\
\text { or behavioural disorders. }\end{array}$ & $\begin{array}{l}\text { Youth identified as delinquent or } \\
\text { displaying antisocial behaviour. }\end{array}$ \\
\hline $\begin{array}{l}\text { Type of } \\
\text { Intervention(s } \\
\text { ) }\end{array}$ & $\begin{array}{l}\text { Parent focused: } \\
\text { Grouped into } 4 \text { broad types: } \\
\text { Behavioural parent training, } \\
\text { Functional assessment, Videotapes }\end{array}$ & $\begin{array}{l}\text { Primary, secondary and } \\
\text { tertiary family-based } \\
\text { prevention programmes: } \\
\text { home visiting, day }\end{array}$ & $\begin{array}{l}\text { Child skills training } \\
\text { programmes focused on } \\
\text { prevention of antisocial } \\
\text { behaviour }\end{array}$ & $\begin{array}{l}\text { School based interventions } \\
\text { designed to reduce aggression } \\
\text { and violence: training in skills of } \\
\text { non-response, training to } \\
\end{array}$ & $\begin{array}{l}\text { Social skills training } \\
\text { interventions: } \\
22 \text { studies included } \\
\text { comprehensive, }\end{array}$ & $\begin{array}{l}\text { Institutional and non- } \\
\text { institutional counselling and } \\
\text { casework or service brokerage } \\
\text { type services }\end{array}$ \\
\hline
\end{tabular}




\begin{tabular}{|c|c|c|c|c|c|c|}
\hline & $\begin{array}{l}\text { and Relationship-focused } \\
\text { interventions } \\
\text { Teacher focused: } \\
\text { Reward system and response cost } \\
\text { systems applied in the classroom } \\
\text { Child focused: } \\
\text { Therapeutic preschools, direct child } \\
\text { training programmes, contingency } \\
\text { systems and videotape programmes } \\
\text { Combination of the above }\end{array}$ & $\begin{array}{l}\text { care/preschool } \\
\text { programmes, school-based } \\
\text { programmes, } \\
\text { home/community } \\
\text { programmes and multi } \\
\text { systemic therapy } \\
\text { programmes. }\end{array}$ & & improve relationship skills & $\begin{array}{l}\text { multimodal and multi- } \\
\text { content training } \\
\text { procedures such as direct } \\
\text { instruction, modelling, } \\
\text { role-playing, rehearsal, } \\
\text { group discussion and } \\
\text { feedback } \\
13 \text { studies used } \\
\text { commercially available } \\
\text { social-skills training } \\
\text { programmes. }\end{array}$ & \\
\hline Results & $\begin{array}{l}\text { Effects of programmes for } \\
\text { preventing aggressive } \\
\text { behaviour in preschoolers are } \\
\text { modest } \\
\text { - } 8 \text { studies used a primarily } \\
\text { behavioural approach and } 8 \\
\text { included cognitive behavioural } \\
\text { principles or psychosocial } \\
\text { interactional approaches as } \\
\text { well. } \\
\text { - Both types of studies showed } \\
\text { equally positive results } \\
\text { Imaginative play training } \\
\text { significantly affected several } \\
\text { play behaviours, but not } \\
\text { aggression. Positive social play } \\
\text { alone does not therefore appear } \\
\text { to be effective in reducing } \\
\text { aggression } \\
\text { - The magnitude of the results } \\
\text { were not related to the duration } \\
\text { of treatment which varied } \\
\text { widely }\end{array}$ & $\begin{array}{l}\frac{\text { Mean effect size }}{\text { All outcomes }} \\
=0.223 \\
\text { All delinquency outcomes } \\
=0.321 \\
\begin{array}{l}\text { All antisocial behaviour } \\
\text { outcomes } \\
=0.196\end{array}\end{array}$ & $\begin{array}{l}\text { Mean effect size } \\
\text { All outcomes } \\
=0.38 \text { (post-intervention) } \\
=0.28 \text { (at follow-up) } \\
\text { Delinquency/ police } \\
\text { contact } \\
=0.16 \text { ( }<<.05 \text { ) } \\
\text { Effects were smaller for } \\
\text { changes in antisocial } \\
\text { behaviour than on related } \\
\text { social and cognitive } \\
\text { measures. }\end{array}$ & $\begin{array}{l}\text { Mean effect size }(95 \% C I) \\
\text { Aggressive behaviours } \\
=-0.36 \text { ( }-0.54 \text { to }-0.19) \\
\text { (in favour of a reduction of } \\
\text { aggression with the intervention) } \\
\text { School /agency responses } \\
=-0.59 \text { (-1.18 to } 0.01) \\
\text { (in favour of a reduction in } \\
\text { school or agency actions with } \\
\text { intervention) }\end{array}$ & $\begin{array}{l}\text { Mean effect size } \\
\text { All outcomes } \\
=0.199 \text { (in favour of the } \\
\text { intervention) }\end{array}$ & $\begin{array}{l}\text { Mean effect size } \\
\text { Delinquency outcomes across } \\
\text { all treatment modalities } \\
\text { Minority youths } \\
=0.11 \\
\text { Majority youths } \\
=0.17\end{array}$ \\
\hline
\end{tabular}




\begin{tabular}{|c|c|c|c|c|c|c|}
\hline $\begin{array}{l}\text { Author's } \\
\text { conclusion }\end{array}$ & $\begin{array}{l}\text { - Scant treatment literature for } \\
\text { aggression and disruptive } \\
\text { behaviour of preschoolers } \\
\text { shows very modest results even } \\
\text { for lengthy interventions. } \\
\text { However methodological and } \\
\text { design factors temper this } \\
\text { conclusion } \\
\text { - Studies that show a positive } \\
\text { effect are likely to include } \\
\text { behavioural interventions }\end{array}$ & $\begin{array}{l}\text { - } \\
\text { Family-based } \\
\text { programmes have a } \\
\text { positive effect } \\
\text { - } \quad \text { in reducing } \\
\text { delinquency and } \\
\text { antisocial child } \\
\text { behaviour }\end{array}$ & $\begin{array}{l}\text { - Studies demonstrate } \\
\text { a small, positive } \\
\text { overall effect in the } \\
\text { efficacy of social } \\
\text { skills training in } \\
\text { preventing antisocial } \\
\text { behaviour in } \\
\text { childhood and youth }\end{array}$ & $\begin{array}{l}\text { School-based violence } \\
\text { prevention programmes } \\
\text { produce modest reductions } \\
\text { in aggressive and violent } \\
\text { behaviour, and reductions } \\
\text { in school and agency } \\
\text { actions in response to such } \\
\text { behaviours }\end{array}$ & $\begin{array}{l}\text { - Social skills } \\
\text { programmes only } \\
\text { have a small effect } \\
\text { on outcomes for } \\
\text { students with } \\
\text { emotional or } \\
\text { behavioural } \\
\text { disorders }\end{array}$ & $\begin{array}{l}\text { Mainstream service } \\
\text { programmes for ethnic } \\
\text { minority juvenile } \\
\text { delinquents without cultural } \\
\text { tailoring showed positive } \\
\text { overall effects on } \\
\text { delinquent behaviour, } \\
\text { school participation, peer } \\
\text { relations, academic } \\
\text { achievement, behaviour } \\
\text { problems, psychological } \\
\text { adjustment and attitudes }\end{array}$ \\
\hline $\begin{array}{l}\text { Reviewers' } \\
\text { conclusion }\end{array}$ & $\begin{array}{l}\text { This review includes a wide } \\
\text { range of study designs and no } \\
\text { quantitative data is presented, } \\
\text { making it difficult to assess the } \\
\text { quality and reliability of the } \\
\text { authors' conclusions. } \\
\text { The principal conclusion that } \\
\text { can be drawn from the study is } \\
\text { that there appears to be less } \\
\text { evidence about programmes for } \\
\text { this age group. }\end{array}$ & $\begin{array}{l}\text { This review relied on } \\
\text { hand searching and } \\
\text { contacting experts in } \\
\text { the field and did not } \\
\text { include searching of } \\
\text { electronic databases. } \\
\text { This carries a } \\
\text { substantial risk of } \\
\text { bias, which } \\
\text { undermines the } \\
\text { conclusions of this } \\
\text { review } \\
\text { The review describes } \\
\text { a number of } \\
\text { individual family- } \\
\text { based programmes } \\
\text { that have been shown } \\
\text { to be effective in } \\
\text { reducing delinquency } \\
\text { \& anti-social child } \\
\text { behaviour (see } \\
\text { examples of } \\
\text { successful } \\
\text { programmes) but } \\
\text { other findings should } \\
\text { be treated with } \\
\text { caution }\end{array}$ & 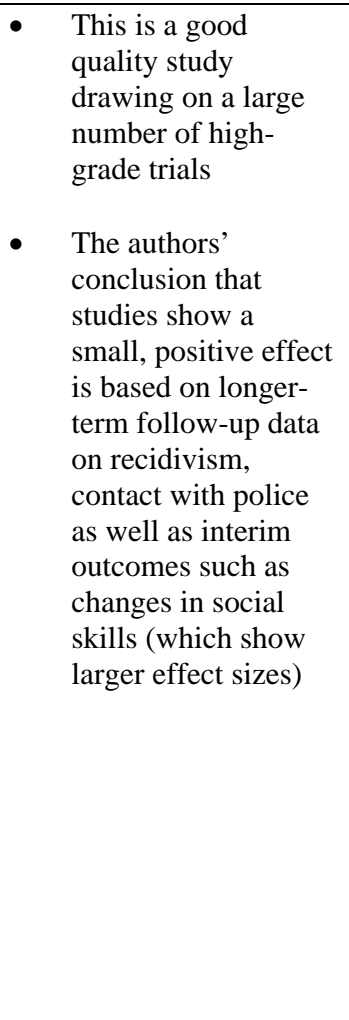 & $\begin{array}{l}\text { This is a good quality } \\
\text { review that uses meta- } \\
\text { analysis to compare the } \\
\text { relative effectiveness of } \\
\text { programmes in by age and } \\
\text { sex } \\
\text { - The review provides good } \\
\text { evidence of positive } \\
\text { changes in aggressive } \\
\text { behaviour, particularly for } \\
\text { programmes aimed at } \\
\text { improving relationship } \\
\text { skills and social context } \\
\text { There is evidence from a } \\
\text { small number of studies that } \\
\text { these effects are maintained } \\
\text { at 1year } \\
\text { Secondary school-based } \\
\text { interventions appear to be } \\
\text { more effective that primary } \\
\text { school based interventions } \\
\text { although this may be due to } \\
\text { the small number of studies } \\
\text { in the latter category }\end{array}$ & $\begin{array}{l}\text { - Limitations in terms } \\
\text { of the amount of } \\
\text { data presented in } \\
\text { this review have } \\
\text { resulted in a } \\
\text { relatively low } \\
\text { quality score: the } \\
\text { data presented } \\
\text { appears to support } \\
\text { the authors' } \\
\text { conclusion that } \\
\text { social skills training } \\
\text { programmes for } \\
\text { children already } \\
\text { exhibiting problem } \\
\text { behaviours have } \\
\text { only a limited effect } \\
\text { on disruptive } \\
\text { behaviour and } \\
\text { aggression. } \\
\text { Other data presented } \\
\text { in the report point to } \\
\text { more positive results } \\
\text { for interim outcomes } \\
\text { such as anxiety and } \\
\text { social relations \& } \\
\text { social behaviour }\end{array}$ & $\begin{array}{l}\text { The purpose of this review } \\
\text { was to establish whether } \\
\text { mainstream programmes to } \\
\text { tackle juvenile delinquency } \\
\text { are more or less effective } \\
\text { with majority or minority } \\
\text { youth } \\
\text { The authors' conclusions } \\
\text { that overall effects for all } \\
\text { programmes combined are } \\
\text { small and that similar } \\
\text { results are observed in } \\
\text { minority \& majority youth } \\
\text { reflects the data presented } \\
\text { in their meta-analysis. } \\
\text { However, the lack of a clear } \\
\text { search strategy means that } \\
\text { these results need to be } \\
\text { interpreted with caution }\end{array}$ \\
\hline
\end{tabular}




\begin{tabular}{|l|c|c|c|c|c|c|}
\hline & & & & $\begin{array}{l}\text { The publication bias may } \\
\text { mean that this study over- } \\
\text { estimates the positive } \\
\text { results obtained }\end{array}$ & \\
\hline $\begin{array}{l}\text { Quality } \\
\text { Score }\end{array}$ & 9 & 8 & 11 & 13 & 8 \\
\hline
\end{tabular}




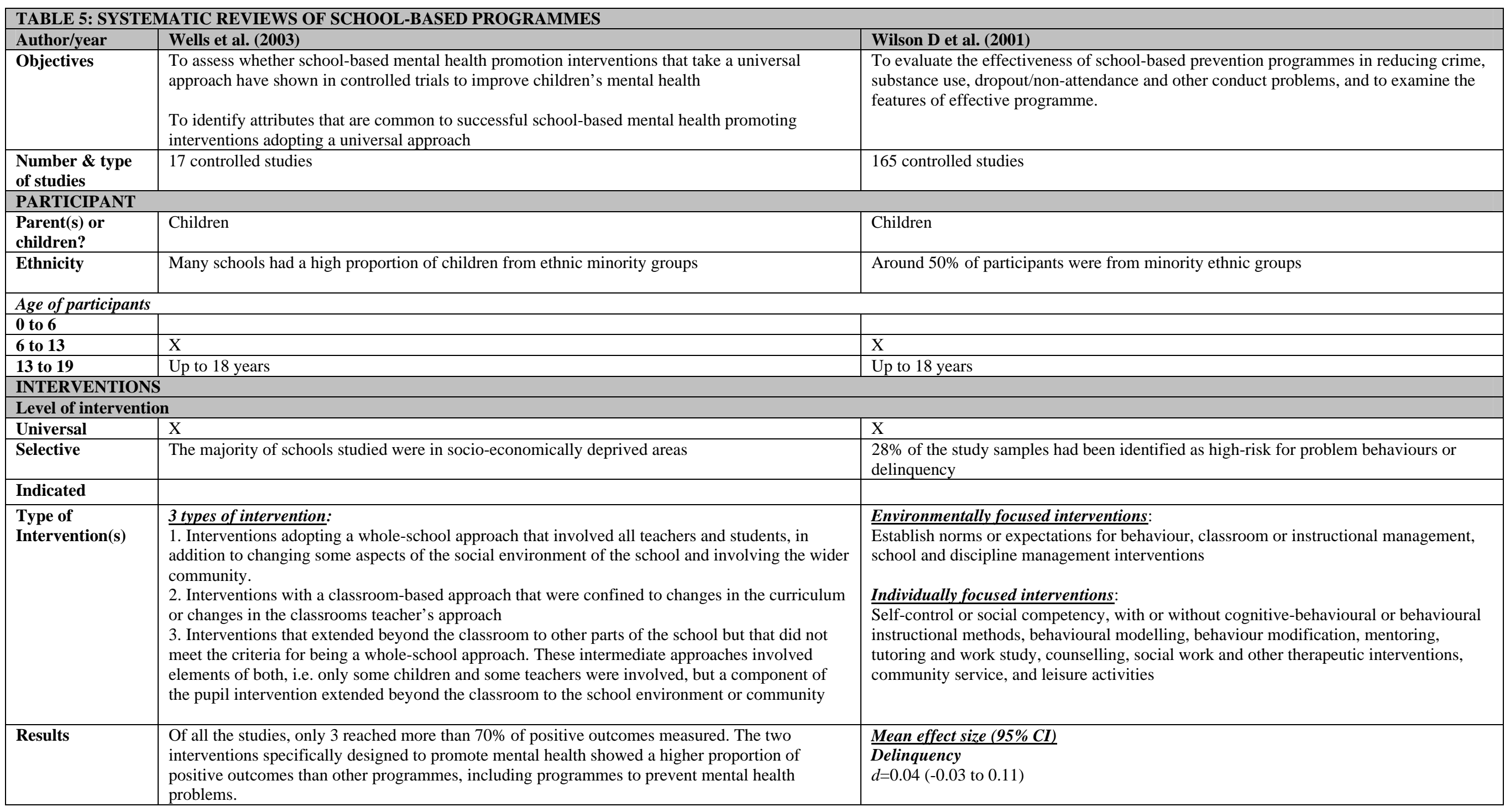




\begin{tabular}{|c|c|c|}
\hline & $\begin{array}{l}\text { The two programmes that adopted a whole-school approach or a beyond school approach showed } \\
\text { a higher percentage of positive results ( } 95 \% \text { and } 100 \%)\end{array}$ & $\begin{array}{l}\text { Dropout/non-attendance } \\
d=0.16(0.05 \text { to } 0.27) \\
\text { Other problem behaviours } \\
d=0.17(0.09 \text { to } 0.25)\end{array}$ \\
\hline $\begin{array}{l}\text { Authors' } \\
\text { conclusions }\end{array}$ & $\begin{array}{l}\text { - There is positive evidence of the effectiveness of programmes that take a whole-school } \\
\text { approach, aimed at the promotion of mental health as opposed to the prevention of mental } \\
\text { illness } \\
\text { - The included reviews provide evidence that universal school mental health promotion } \\
\text { programmes can be effective and suggest that long-term interventions promoting the positive } \\
\text { mental health of all pupils and involving changes to the school climate are likely to be more } \\
\text { successful than brief classroom-based mental illness prevention programmes }\end{array}$ & $\begin{array}{l}\text { This review shows that school-based prevention practices appear to be effective in } \\
\text { reducing alcohol and drug use, dropout and non-attendance, and other conduct } \\
\text { problems. }\end{array}$ \\
\hline $\begin{array}{l}\text { Reviewers' } \\
\text { conclusions }\end{array}$ & $\begin{array}{l}\text { - This is a good quality review, which provides some evidence to demonstrate the } \\
\text { effectiveness of whole-school programmes, although this result is based on a small number } \\
\text { of studies }\end{array}$ & $\begin{array}{l}\text { - There is evidence to support the effectiveness of these interventions, but the } \\
\text { magnitude of effects is small for all the outcomes }\end{array}$ \\
\hline Quality score & 10 & 11 \\
\hline
\end{tabular}




\begin{tabular}{|c|c|c|c|c|c|c|c|}
\hline $\begin{array}{l}\text { TABLE 6: GENER } \\
\text { Author/ year }\end{array}$ & $\begin{array}{l}\text { L REVIEWS } \\
\text { Andrews \& } \\
\text { Wilkinson (2002) }\end{array}$ & Dubois et al (2002) & $\begin{array}{l}\text { Durlak \& Wells } \\
\text { (1997) }\end{array}$ & Durlak \& Wells (1998) & $\begin{array}{l}\text { Greenberg et al. } \\
\text { (2001) }\end{array}$ & $\begin{array}{l}\text { Kulic \& Horne } \\
\text { (2004) }\end{array}$ & Nelson et al. (2003) \\
\hline Objectives & $\begin{array}{l}\text { To establish the } \\
\text { value of risk-factor } \\
\text { reduction or } \\
\text { enhanced coping } \\
\text { strategies in } \\
\text { preventing the } \\
\text { onset of anxiety, } \\
\text { affective or } \\
\text { substance-use } \\
\text { disorders }\end{array}$ & $\begin{array}{l}\text { To assess the effects } \\
\text { of mentoring } \\
\text { programmes on } \\
\text { youth }\end{array}$ & $\begin{array}{l}\text { To review the } \\
\text { effectiveness of } \\
\text { interventions to } \\
\text { reduce the future } \\
\text { incidence of } \\
\text { adjustment problems } \\
\text { in under } 18 \mathrm{~s}\end{array}$ & $\begin{array}{l}\text { To evaluate the } \\
\text { effectiveness of indicated } \\
\text { preventive mental health } \\
\text { interventions for children } \\
\text { and adolescents }\end{array}$ & $\begin{array}{l}\text { To review prevention } \\
\text { programmes found to } \\
\text { produce } \\
\text { improvements in } \\
\text { psychological } \\
\text { symptomology or in } \\
\text { factors associated } \\
\text { with increased risk of } \\
\text { child mental disorders }\end{array}$ & $\begin{array}{l}\text { To identify effective } \\
\text { group approaches to } \\
\text { prevention with } \\
\text { adolescents and } \\
\text { children }\end{array}$ & $\begin{array}{l}\text { To determine the effectiveness of } \\
\text { preschool prevention programmes for } \\
\text { disadvantaged children's cognitive and } \\
\text { social development }\end{array}$ \\
\hline $\begin{array}{l}\text { Number \& type of } \\
\text { studies }\end{array}$ & 20 RCTs & 55 controlled studies & 177 controlled studies & 121 controlled studies & $\begin{array}{l}34 \text { studies using } \\
\text { randomized-trial } \\
\text { design/ quasi- } \\
\text { experimental design }\end{array}$ & $\begin{array}{l}80 \text { quasi-experimental } \\
\text { or experimental } \\
\text { studies }\end{array}$ & $\begin{array}{l}34 \text { studies with a prospective design and } \\
\text { a control group. }\end{array}$ \\
\hline \multicolumn{8}{|l|}{ PARTICIPANTS } \\
\hline $\begin{array}{l}\text { Parent(s) or } \\
\text { children? }\end{array}$ & $\begin{array}{l}\text { Children and } \\
\text { adolescents }\end{array}$ & $\begin{array}{l}\text { Children and } \\
\text { adolescents }\end{array}$ & $\begin{array}{l}\text { Children and } \\
\text { adolescents }\end{array}$ & Children and adolescents & $\begin{array}{l}\text { Children and } \\
\text { adolescents }\end{array}$ & $\begin{array}{l}\text { Children and } \\
\text { adolescents }\end{array}$ & Children \\
\hline Ethnicity & Not stated & Not stated & Not stated & Not stated & Not stated & Mixed & $\begin{array}{l}\text { More than half of the interventions } \\
\text { targeted African- American children. }\end{array}$ \\
\hline \multicolumn{8}{|l|}{ Age of participants } \\
\hline 0 to 6 & $\mathrm{X}$ & $\mathrm{X}$ & $\mathrm{X}$ & $\mathrm{X}$ & & 2 to 17 & Under 5 \\
\hline 6 to 13 & $\mathrm{X}$ & $\mathrm{X}$ & $\mathrm{X}$ & $\mathrm{X}$ & $\mathrm{X}$ & $\mathrm{X}$ & \\
\hline 13 to 19 & $\begin{array}{l}\text { Young people } \\
\text { under } 19\end{array}$ & $\begin{array}{l}\text { Youth with a mean } \\
\text { age of less than } 19\end{array}$ & $\mathrm{X}$ & Mean age less than 19 & 5 to 18 years & 2 to 17 & \\
\hline \multicolumn{8}{|c|}{ INTERVENTIONS } \\
\hline \multicolumn{8}{|c|}{ Level of intervention } \\
\hline Universal & $\mathrm{X}$ & $\mathrm{X}$ & $\begin{array}{l}\text { Normal populations } \\
\text { of children and } \\
\text { adolescents }\end{array}$ & & $\mathrm{X}$ & $\mathrm{X}$ & $\begin{array}{l}\text { Children who did not manifest mental } \\
\text { health or developmental problems }\end{array}$ \\
\hline Selective & $\mathrm{X}$ & $\mathrm{X}$ & & & $\mathrm{X}$ & $\mathrm{X}$ & $\mathrm{X}$ \\
\hline Indicated & & & & $\begin{array}{l}\text { Children with sub-clinical } \\
\text { problems (internalising, } \\
\text { externalising, mixed } \\
\text { adjustment problems, poor } \\
\text { peer relations and low }\end{array}$ & $\mathrm{X}$ & & \\
\hline
\end{tabular}




\begin{tabular}{|c|c|c|c|c|c|c|c|}
\hline & & & & $\begin{array}{l}\text { levels of academic } \\
\text { performance) }\end{array}$ & & & \\
\hline $\begin{array}{l}\text { Type of } \\
\text { intervention(s) }\end{array}$ & $\begin{array}{l}\text { Predominantly } \\
\text { cognitive } \\
\text { behavioural therapy } \\
\text { interventions, } \\
\text { delivered by } \\
\text { teachers, clinicians } \\
\text { or psychologists }\end{array}$ & $\begin{array}{l}\text { One-to-one } \\
\text { mentoring } \\
\text { programmes } \\
\text { delivered in school } \\
\text { \& community } \\
\text { settings }\end{array}$ & $\begin{array}{l}\text { Person-centred } \\
\text { Affective education, } \\
\text { problem-solving } \\
\text { Environment-centred } \\
\text { School programmes: } \\
\text { changes in classroom } \\
\text { setting, school, } \\
\text { classroom social skills } \\
\text { training. } \\
\text { Parenting } \\
\text { programmes: home } \\
\text { visiting, parent } \\
\text { training. } \\
\\
\text { Transition } \\
\text { School-transition, } \\
\text { dealing with divorce/ } \\
\text { bereavement, first- } \\
\text { time mothers, } \\
\text { medical/dental } \\
\text { procedures }\end{array}$ & 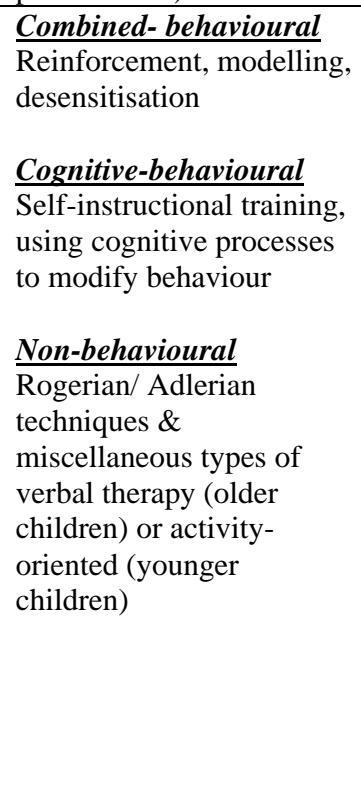 & $\begin{array}{l}\text { Universal preventive } \\
\text { programmes } \\
\text { Violence prevention, } \\
\text { social/ cognitive skill- } \\
\text { building programs, } \\
\text { school-transition } \\
\text { Externalising } \\
\text { behaviours (selected } \\
\text { or indicated) } \\
\text { Child-focused, adult- } \\
\text { support/ mentoring, } \\
\text { multi-component } \\
\text { Internalising } \\
\text { behaviours } \\
\text { Universal depression- } \\
\text { prevention, mood } \\
\text { disorder prevention, } \\
\text { anxiety \& stress } \\
\text { prevention }\end{array}$ & $\begin{array}{l}\text { Interventions included } \\
\text { psycho-educational } \\
\text { groups, counselling/ } \\
\text { interpersonal problem } \\
\text { solving, self-esteem } \\
\text { programmes } \\
\\
80 \% \text { of programmes } \\
\text { were delivered in } \\
\text { schools }\end{array}$ & $\begin{array}{l}\text { Universal or selected pre-school } \\
\text { prevention programs to promote } \\
\text { children's competence and well-being } \\
\text { and/or prevent negative outcomes for } \\
\text { children. } \\
\text { Most frequently provided programme } \\
\text { component was home visitation, parent } \\
\text { training, and pre-school education. } 79 \% \\
\text { of programmes offered more than one } \\
\text { component. }\end{array}$ \\
\hline Results & $\begin{array}{l}\text { CBT to prevent } \\
\text { depressive } \\
\text { disorders may be } \\
\text { effective in both } \\
\text { universal and } \\
\text { targeted groups } \\
\text { and in preventing } \\
\text { anxiety disorders in } \\
\text { children identified } \\
\text { as being at risk }\end{array}$ & $\begin{array}{l}\frac{\text { Overall effect }}{\text { of youth mentoring }} \\
\text { programmes: } \\
d=0.18 \\
\text { Programmes that } \\
\text { included structured } \\
\text { activities and on- } \\
\text { going training were } \\
\text { more effective than } \\
\text { those without, as } \\
\text { were programmes } \\
\text { that involved } \\
\text { parents }\end{array}$ & 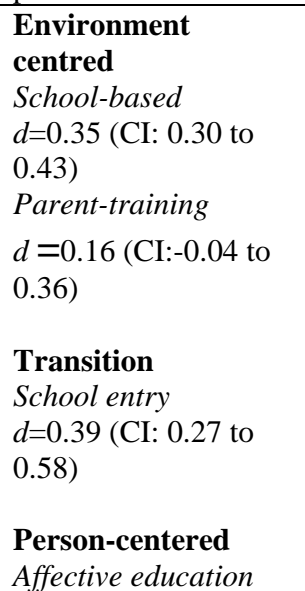 & 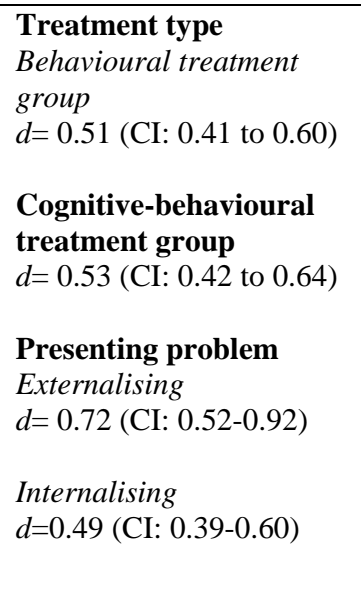 & $\begin{array}{l}\text { No formal results } \\
\text { given: individual } \\
\text { qualitative } \\
\text { descriptions of each } \\
\text { programme but no } \\
\text { summary of results } \\
\text { across the three } \\
\text { programme } \\
\text { categories. } \\
\text { Only studies with } \\
\text { positive effects were } \\
\text { included in the } \\
\text { review. }\end{array}$ & $\begin{array}{l}\text { No data reported on } \\
\text { outcomes: paper } \\
\text { describes } \\
\text { characteristics of } \\
\text { studies } \\
\text { (methodological } \\
\text { characteristics \& } \\
\text { change agent } \\
\text { characteristics) but } \\
\text { without reference to } \\
\text { overall effect of } \\
\text { interventions }\end{array}$ & $\begin{array}{l}\text { Cognitive impacts (all programmes) } \\
\text { greatest during the pre-school period } \\
(d=0.52) \text { but were still evident during } \\
\text { kindergarten to Grade } 8(d=0.3) \text {. } \\
\text { Social-emotional impacts on children } \\
\text { were similar up to Grade } 8(d=0.27) \text { and } \\
\text { high school and beyond }(d=0.33) \text { as } \\
\text { were parent-family wellness impacts at } \\
\text { preschool ( } d=0.33) \text { and up to Grade } 8 \\
(d=0.30) .\end{array}$ \\
\hline
\end{tabular}




\begin{tabular}{|c|c|c|c|c|c|c|c|}
\hline & & & $\begin{array}{l}\text { Aged 2-7 } \\
d=0.70 \text { (CI: } 0.49 \text { to } \\
0.91) \\
\text { Aged } 7-11 \\
d=0.24 \text { (CI: } 0.18 \text { to } \\
0.31) \\
\text { Over } 11 \\
d=0.33 \text { (CI: } 0.18 \text { to } \\
0.48 \text { ) } \\
\\
\text { Interpersonal } \\
\text { problem solving } \\
\text { Children } 2-7 \\
d=0.93 \text { (CI: } 0.66 \text { to } \\
1.19) \\
\text { Children } 7-11 \\
d=0.36 \text { (CI: } 0.24 \text { to } \\
0.48 \text { ) } \\
\text { Other person centred } \\
\text { programmes } \\
\text { Behavioural approach } \\
d=0.49 \text { (CI: } 0.38 \text { to } \\
0.59) \\
\text { Non-behavioural } \\
\text { approach } \\
d=0.25 \text { (CI: } 0.06 \text { to } \\
0.444)\end{array}$ & & & & \\
\hline $\begin{array}{l}\text { Authors' } \\
\text { conclusions }\end{array}$ & $\begin{array}{l}\text { Evidence that } \\
\text { some anxiety, } \\
\text { affective and } \\
\text { substance-use } \\
\text { disorders can } \\
\text { be prevented. } \\
\text { - Trials show that } \\
\text { interventions are } \\
\text { efficacious but } \\
\text { there is limited } \\
\text { evidence about }\end{array}$ & $\begin{array}{l}\text { Some evidence } \\
\text { of the } \\
\text { effectiveness of } \\
\text { youth mentoring } \\
\text { programmes. } \\
\text { However, the } \\
\text { average } \\
\text { estimated effect } \\
\text { size of } 0.14 \text { is } \\
\text { consistent with } \\
\text { only a small } \\
\text { effect }\end{array}$ & $\begin{array}{l}\text { Most types of primary } \\
\text { prevention achieved } \\
\text { significant positive } \\
\text { effects in both } \\
\text { reducing problems } \\
\text { and increasing } \\
\text { competencies and } \\
\text { problem-solving } \\
\text { skills, with the } \\
\text { exception of parent- } \\
\text { training (which did } \\
\text { not reach } \\
\text { significance). }\end{array}$ & $\begin{array}{l}\text { Indicated prevention } \\
\text { produces positive } \\
\text { effects that are } \\
\text { statistically and } \\
\text { practically significant } \\
\text { - Mean effects achieved } \\
\text { by cognitive- } \\
\text { behavioural or } \\
\text { behavioural } \\
\text { programmes are } \\
\text { moderately high in } \\
\text { magnitude }\end{array}$ & $\begin{array}{l}\text { - There is a growing } \\
\text { number of } \\
\text { programmes with } \\
\text { documented } \\
\text { evidence of } \\
\text { beneficial impact } \\
\text { on the reduction of } \\
\text { psychiatric } \\
\text { symptomology } \\
\text { - More work is } \\
\text { needed to evaluate } \\
\text { the }\end{array}$ & See below & $\begin{array}{l}\text { Pre-school prevention programmes } \\
\text { have positive short, medium and } \\
\text { long-term impacts on children's } \\
\text { cognitive, social-emotional } \\
\text { functioning and family wellness } \\
\text { that last up to } 9 \text { years of age. } \\
\text { - Effect sizes are in the small to } \\
\text { moderate range. }\end{array}$ \\
\hline
\end{tabular}




\begin{tabular}{|c|c|c|c|c|c|c|c|}
\hline & $\begin{array}{l}\text { effectiveness in } \\
\text { routine practice }\end{array}$ & & & $\begin{array}{l}\text { - The highest overall } \\
\text { mean effect was found } \\
\text { for participants } \\
\text { presenting with } \\
\text { externalising disorders }\end{array}$ & $\begin{array}{l}\text { implementation } \\
\text { process and } \\
\text { impact of widely } \\
\text { disseminated } \\
\text { programme } \\
\text { models } \\
\end{array}$ & & \\
\hline $\begin{array}{l}\text { Reviewers' } \\
\text { conclusions }\end{array}$ & $\begin{array}{l}\text { This is a poor } \\
\text { quality review } \\
\text { that does not } \\
\text { appear to have } \\
\text { used a } \\
\text { systematic } \\
\text { search } \\
\text { The review } \\
\text { identifies a } \\
\text { number of } \\
\text { successful } \\
\text { programmes } \\
\text { but the serious } \\
\text { design flaws in } \\
\text { the study mean } \\
\text { that its } \\
\text { conclusions } \\
\text { should be } \\
\text { treated with } \\
\text { caution }\end{array}$ & $\begin{array}{l}\text { This is a } \\
\text { reasonable } \\
\text { quality review } \\
\text { which uses } \\
\text { meta-analysis } \\
\text { to compare the } \\
\text { overall } \\
\text { effectiveness } \\
\text { of youth } \\
\text { mentoring } \\
\text { programmes } \\
\text { The authors } \\
\text { present } \\
\text { evidence from } \\
\text { meta-analysis } \\
\text { to support their } \\
\text { conclusions } \\
\text { The review } \\
\text { includes some } \\
\text { non- } \\
\text { randomised } \\
\text { control trials } \\
\text { and should } \\
\text { therefore be } \\
\text { treated with } \\
\text { caution. }\end{array}$ & $\begin{array}{l}\text { This is a } \\
\text { reasonably high } \\
\text { quality (and } \\
\text { widely-cited) } \\
\text { review, which } \\
\text { uses meta- } \\
\text { analysis to assess } \\
\text { the overall } \\
\text { effectiveness of } \\
\text { secondary } \\
\text { presentation } \\
\text { programmes } \\
\\
\text { The results of this } \\
\text { review should be } \\
\text { interpreted with } \\
\text { caution because it } \\
\text { includes some } \\
\text { non-randomised } \\
\text { controlled trials }\end{array}$ & $\begin{array}{l}\text { See Durlak \& Wells } \\
\text { (1997) }\end{array}$ & $\begin{array}{l}\text { The purpose of } \\
\text { this review is to } \\
\text { identify successful } \\
\text { programmes only. } \\
\text { This means that it } \\
\text { is not possible to } \\
\text { draw any } \\
\text { conclusions about } \\
\text { the overall } \\
\text { effectiveness of } \\
\text { different } \\
\text { programmes or } \\
\text { programme types }\end{array}$ & $\begin{array}{l}\text { This poor quality } \\
\text { review is primarily } \\
\text { focused on the } \\
\text { methodological } \\
\text { characteristics of } \\
\text { included studies } \\
\text { and does not } \\
\text { present data on the } \\
\text { relative } \\
\text { effectiveness of } \\
\text { different } \\
\text { interventions } \\
\text { The review } \\
\text { discusses some of } \\
\text { the factors that } \\
\text { appear to } \\
\text { influence } \\
\text { programme } \\
\text { effectiveness (see } \\
\text { section 4) }\end{array}$ & $\begin{array}{l}\text { This is a reasonable quality review } \\
\text { providing evidence from controlled } \\
\text { studies that pre-school prevention } \\
\text { programmes for disadvantaged } \\
\text { children have beneficial effects on } \\
\text { both cognitive and social-emotional, } \\
\text { with the greatest benefit on cognition } \\
\text { - A small number of studies show that } \\
\text { these benefits are maintained over } \\
\text { time }\end{array}$ \\
\hline Quality Score & 5 & 9 & 9 & 9 & 4 & 4 & 8 \\
\hline
\end{tabular}


